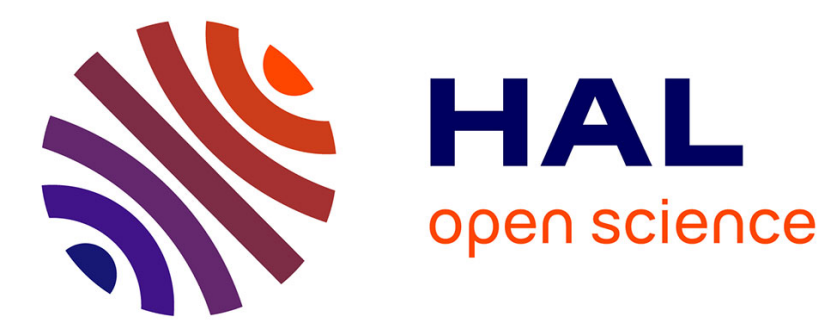

\title{
The archimandrite and the astronomer. The visit of Chrysanthos Notaras to Giovanni Domenico Cassini: a new approach \\ Vassa Kontouma
}

\section{- To cite this version:}

Vassa Kontouma. The archimandrite and the astronomer. The visit of Chrysanthos Notaras to Giovanni Domenico Cassini: a new approach. Confessionalization and/as Knowledge Transfer in the Greek Orthodox Church, 23, Harrassowitz Verlag, pp.233-272, 2021, Episteme in Bewegung Beiträge zu einer transdisziplinären Wissensgeschichte, 10.13173/9783447117227.233 . hal-03539889

\section{HAL Id: hal-03539889 \\ https://hal.science/hal-03539889}

Submitted on 22 Jan 2022

HAL is a multi-disciplinary open access archive for the deposit and dissemination of scientific research documents, whether they are published or not. The documents may come from teaching and research institutions in France or abroad, or from public or private research centers.
L'archive ouverte pluridisciplinaire HAL, est destinée au dépôt et à la diffusion de documents scientifiques de niveau recherche, publiés ou non, émanant des établissements d'enseignement et de recherche français ou étrangers, des laboratoires publics ou privés. 


\section{Episteme in Bewegung}

Beiträge zu einer transdisziplinären Wissensgeschichte

Herausgegeben von Gyburg Uhlmann im Auftrag des Sonderforschungsbereichs 980

„Episteme in Bewegung.

Wissenstransfer von der Alten Welt

bis in die Frühe Neuzeit"

\section{Band 23}

2021

Harrassowitz Verlag · Wiesbaden 


\title{
Confessionalization and/as Knowledge Transfer in the Greek Orthodox Church
}

\author{
Edited by \\ Kostas Sarris, Nikolas Pissis and Miltos Pechlivanos
}

2021

Harrassowitz Verlag · Wiesbaden 
Die Reihe „Episteme in Bewegung“ umfasst wissensgeschichtliche Forschungen mit einem systematischen oder historischen Schwerpunkt in der europäischen und nicht-europäischen Vormoderne. Sie fördert transdisziplinäre Beiträge, die sich mit Fragen der Genese und Dynamik von Wissensbeständen befassen, und trägt dadurch zur Etablierung vormoderner Wissensforschung als einer eigenständigen Forschungsperspektive bei.

Publiziert werden Beiträge, die im Umkreis des an der Freien Universität Berlin angesiedelten Sonderforschungsbereichs 980 „Episteme in Bewegung. Wissenstransfer von der Alten Welt bis in die Frühe Neuzeit" entstanden sind.

Herausgeberbeirat:

Anne Eusterschulte (FU Berlin)

Kristiane Hasselmann (FU Berlin)

Andrew James Johnston (FU Berlin)

Jochem Kahl (FU Berlin)

Klaus Krüger (FU Berlin)

Beate La Sala (FU Berlin)

Christoph Markschies (HU Berlin)

Tilo Renz (FU Berlin)

Anita Traninger (FU Berlin)

Gefördert durch die Deutsche Forschungsgemeinschaft (DFG) -

Projektnummer 191249397 - SFB 980.

Abbildung auf dem Umschlag:

„Papas Grec en habits Sacerdotaux“: Joseph Pitton de Tournefort, Relation d'un Voyage du Levant, Paris 1717,

vol. I, p. 117 (Courtesy of the Aikaterini Laskaridis Foundation, Athens)

\section{(1) (1) (}

Dies ist ein Open-Access-Titel, der unter den Bedingungen der CC BY-SA 4.0-Lizenz veröffentlicht wird. Diese erlaubt die kommerzielle Nutzung, Verbreitung und Vervielfältigung in allen Medien.

Weitere Informationen: https://creativecommons.org/licenses/by-sa/4.0/deed.de

Die Bedingungen der CC-Lizenz gelten nur für das Originalmaterial. Die Verwendung von Material aus anderen Quellen (gekennzeichnet durch eine Quellenangabe) wie Schaubilder, Abbildungen, Fotos und Textauszüge erfordert ggf. weitere Nutzungsgenehmigungen durch den jeweiligen Rechteinhaber.

Der Harrassowitz Verlag behält sich das Recht vor, die Veröffentlichung vor unbefugter Nutzung zu schützen. Anträge auf kommerzielle Verwertung, Verwendung von Teilen der Veröffentlichung und/oder Übersetzungen sind an den Harrassowitz Verlag zu richten.

Bibliografische Information der Deutschen Nationalbibliothek

Die Deutsche Nationalbibliothek verzeichnet diese Publikation in der Deutschen

Nationalbibliografie; detaillierte bibliografische Daten sind im Internet

über https://www.dnb.de abrufbar.

Informationen zum Verlagsprogramm finden Sie unter

https://www.harrassowitz-verlag.de

(c) bei den Autor/innen

Verlegt durch Otto Harrassowitz GmbH \& Co. KG, Wiesbaden 2021

Gedruckt auf alterungsbeständigem Papier.

Druck und Verarbeitung: Memminger MedienCentrum AG

Printed in Germany

ISSN 2365-5666

eISSN 2701-2522

DOI: $10.13173 / 2365-5666$
ISBN 978-3-447-11722-7

eISBN 978-3-447-39227-3

DOI: $10.13173 / 9783447117227$ 


\section{The Archimandrite and the Astronomer}

\section{The Visit of Chrysanthos Notaras to Giovanni Domenico Cassini: a new Approach*}

Vassa Kontouma, EPHE, PSL-Paris

On 21 June 1667-the day of the summer solstice-the mathematicians of the French Royal Academy of Sciences drew the prime meridian of the world on the ground of a Paris suburb. Designed as a citadel of science under the supervision of the architect Claude Perrault, the Observatory was quickly built on the same path. In 1669, Louis XIV's minister Jean-Baptiste Colbert invited the Italian astronomer Giovanni Domenico Cassini to lead the institution, where he settled, installing a dynasty of scientists and promoting French science as the most innovative of its time. ${ }^{1}$

Thirty years later, at the summit of his reputation, Cassini generously welcomed to the Observatory an unusual visitor: Chrysanthos Notaras, a literate archimandrite, but also the nephew of the Patriarch Dositheos II of Jerusalem. What was the real purpose of this encounter, and why did it take place in April 1700? In the following contribution, I will try to provide some answers to these questions, by reconsidering and completing the available evidence.

\section{Chrysanthos' visit to Paris and his subsequent reputation in the East}

The testimonies

The archimandrite's visit to Paris is precisely documented by a series of wellknown sources. The first information about it dates from the very moment of his departure from Padova, where he followed the classes of the Greek Catholic professor Nikolaos Komninos-Papadopoulos, studying theology and canon law at the latter's scuola privata. ${ }^{2}$ In a letter dated 8 April 1700, and addressed to Patriarch Dositheos, Komninos-Papadopoulos gives following information:

* This paper is the product of a research carried out in several stages during the years 20172019, in the framework of the workshop 'Confessionalization and/as knowledge transfer in Eastern Christianity' (Berlin, December 2017), of my seminar at the École pratique des hautes études (Paris), and of a visit at Balliol College (Oxford, May 2018) at the invitation of J.-P. Ghobrial, who suggested me its definitive title. My thanks to all colleagues involved in these exchanges.

1 The Paris Observatory keeps a rich collection of manuscripts and archives. See N. Daliès, 'Les archives à la Bibliothèque de l'Observatoire de Paris', Gazette des archives 179 (1997) 321-31. Some of the documents I will refer to below are now online: https://bibnum.obspm.fr.

2 P. Stathi, X $\alpha \varphi \omega \tau \iota \sigma \mu o \tilde{v}$ (Athens 1999) 82-8. Chrysanthos stayed in Padova in the period 1697-1700.

DOI: $10.13173 / 9783447117227.233$ 
[My very dear Chrysanthos] set off with the very noble Sir Răducan ${ }^{3}$ on Great Monday, the 5th April, according to the Italian calendar. Having begun his trip to the Celts, ${ }^{4}$ he tore out of me, not only my heart, but also the pleasure and the glory of my teaching. ${ }^{5}$

The mention of the visit comes from Chrysanthos himself. It appears in one of the archimandrite's most famous works, published in Paris sixteen years later, his Introduction to Geographics and Sphaerics, ${ }^{6}$ as a long parenthesis included in a paragraph dealing with the measurement of the circumference of the Earth:

In the year of Christ 1669 and 1670, Picard, official mathematician of the Royal Academy of the king of France Louis the fourteenth [...] discovered that a celestial degree of the great Circle traces on earth fifty-seven thousand and sixty Parisian toises [...]. However, at the time when this operation [of measurement] was conducted in the Province Vastinensis ${ }^{7}, \mathrm{Mr}$ Giovanni Domenico Cassini was also present, an excellent mathematician and first astronomer of the Royal Academy, freshly arrived from Italy at the invitation of the King-whom I met in Paris in the year of Christ 1700. Now we enjoyed on his part genuine philanthropy: he welcomed us as a friend and lodged us for a whole week in his home (in the Royal Observatory). With him, we observed with the largest telescopes the Moon, Jupiter and the satellite stars which encircle it, the Galaxy and other things. Thus he informed us that he had discovered, through numerous methods and observations, that one minute of the circumference of the Earth, i.e. an average Italic mile, is 5706 feet from Paris [...]. He also instructed us concerning various mathematical measures [...]. We have introduced this account of the measurement of the circumference of the earth in the middle [of our speech], so that

3 On Rădu Cantacuzino, see V. Vasiliu, 'Costantino Brâncoveanu e il Cattolicismo. Alcune notizie nuove intorno alla sua politica religiosa', Ephemerides Dacoromana. Annuario della Scuola romena di Roma 3 (1925) 110-28; P. Cernovodeanu and N. Vătămanu, 'Trois lettres inédites de Jean Comnène', Revue d'Histoire roumaine 11 (1972) 137-45.

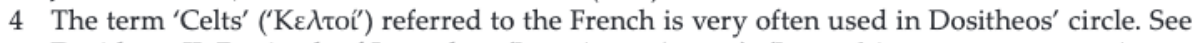

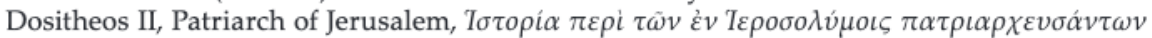
[History concerning the Patriarchs in Jerusalem] (Bucharest 1715 [ca 1722]) 1217 (Book XII, ch. 6,

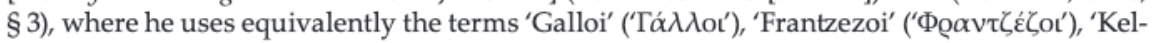

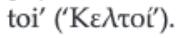

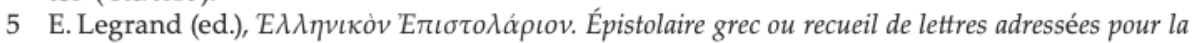
plupart à Chrysanthe Notaras patriarche de Jérusalem par les princes de Valachie et de Moldavie (Paris 1888) 11: 'A

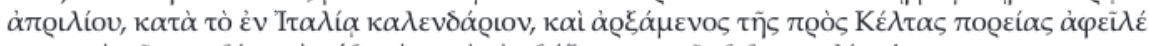

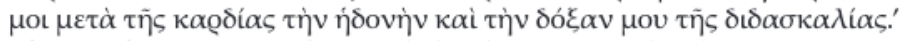

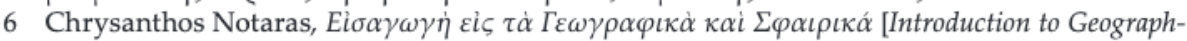

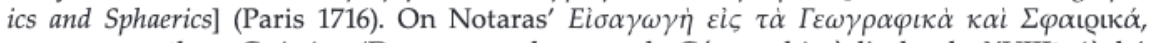
see among others G. Aujac, 'Deux manuels grecs de Géographie à l'aube du XVIII ${ }^{\mathrm{e}}$ siècle',

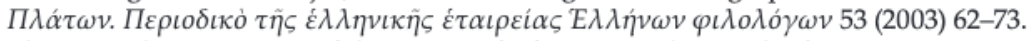

7 The Latin denomination of the region of Gâtinais, in the South of Paris. 
everyone might understand firstly that it has been the subject of careful research $[\ldots]$, and secondly the inherent difficulty thereof $[\ldots] .^{8}$

This detailed account is furthermore corroborated by a third mention evoking Chrysanthos' exchanges with 'the wise men of the Western Church', and particularly with some French theologians of his time. Given in the preface to the History concerning the Patriarchs in Jerusalem-the posthumous work of Dositheos published by his nephew in $1715\left[=\right.$ ca $\left.1722^{9}\right]-$ this account generally condemns the methods of the Jesuits, 'these very wise men, about whom the tears come to me, because they get lost in vain doctrines', but also praises 'almost the entire Gallican Church', which does not share the Jesuit doctrines about papal monarchy and infallibility, and particularly the Church historian Louis Ellies Dupin, whom Chrysanthos met in person in Paris:

For not all Western sages, nor nearly the entirety of the Gallican Church advocate this vain doctrine and error relative to their bishop of Rome, as I have learned myself and attest as true, in full awareness, through the conversation I had with several men in Italy, France, Germany, Poland, and especially in Paris, [...] notably with Louis Ellies Dupin, theologian of the Sorbonne, an admirable and learned man, an erudite and an experienced and trustworthy expert on the Church councils, Holy Fathers and ecclesiastical historians. ${ }^{10}$

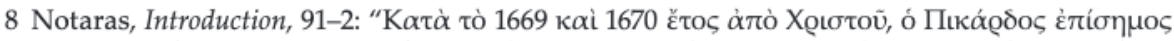

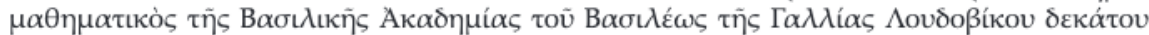

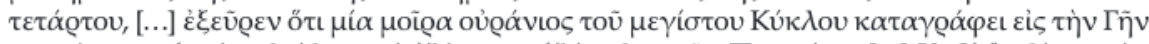

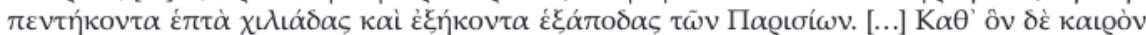

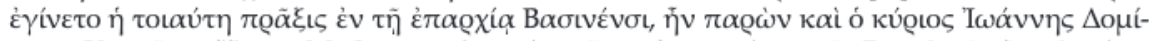

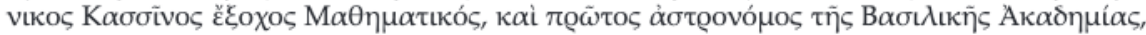

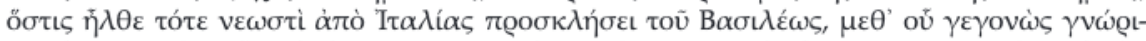

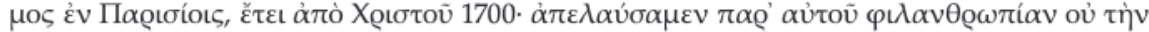

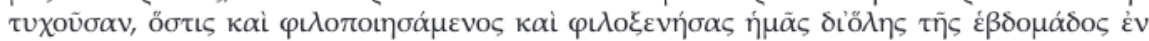

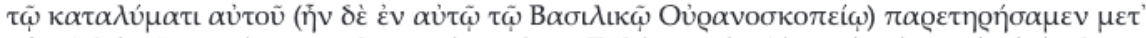

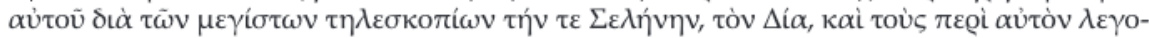

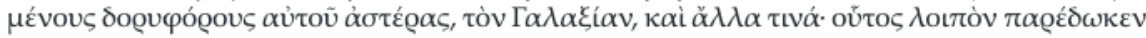

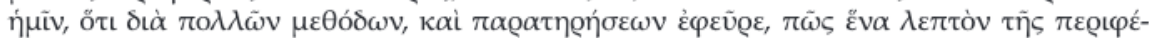

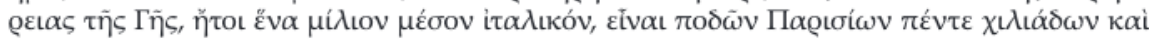

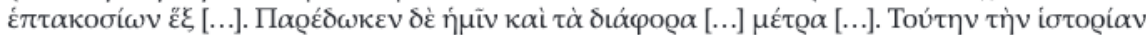

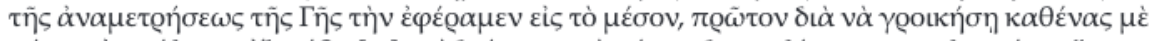

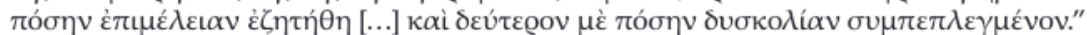

91715 is the publication year indicated on the first edition of the book. It seems however to

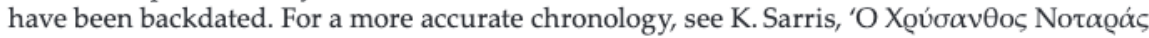

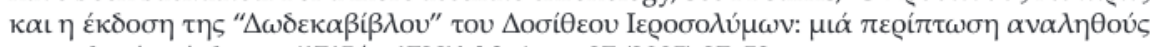

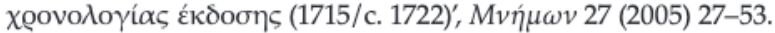

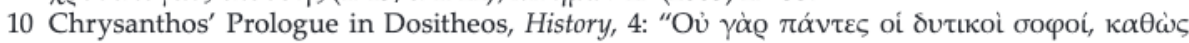

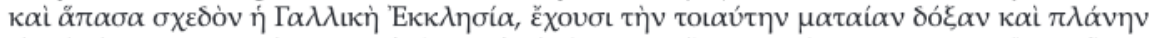

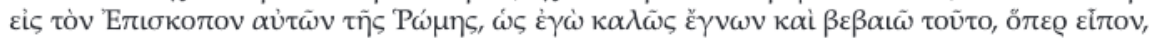

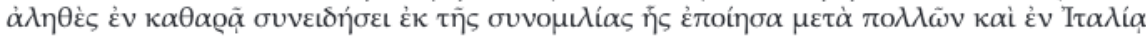

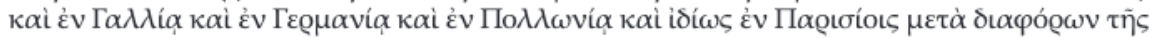


This is also confirmed much later by an indirect testimony of the Dominican Michel Lequien (1661-1733), reported in 1740 by the editor of his Oriens christianus:

Many people saw this man [= Chrysanthos] in Paris when he was younger, [and found that he was] a most learned and very accomplished man, that he had a sweet disposition and was most acceptable to all [...]. 'I declare that I am indebted to him for several reasons': these are the words of Father Lequien, the author of the present work. ${ }^{11}$

Last but not least, an anonymous epigram to the glory of the archimandrite, published ad limina of his Introduction to Geographics and Sphaerics, praises in the following terms his Parisian visit, during which he would appear to have been considered-according to a statement attributed to Cassini-as 'Euclid redivivus':

You visited the cities of so many men, and you came to know their spirit, Excellent man, you who give birth to all forms of wisdom! The cities of the Argeans, Thracians, Dacians, Batavians, Italians And Antenorids [= Venetians] are witnesses to it.

And Paris even more, the city with the great name, testifies to it.

Cassini, this man with elevated spirit, admired you there,

He admired your knowledge given by God and your language,

And thought he was talking to another Euclid. ${ }^{12}$

It is interesting to see that all these flattering reports were taken for granted and even elaborated by Konstantinos Nikolopoulos [or Nicolopoulo] in Michaud's Bio-

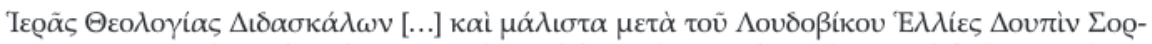

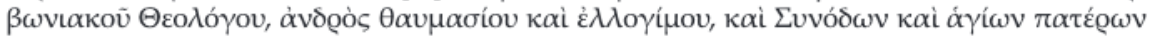

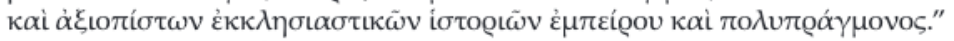

11 M. Lequien, Oriens christianus in quatuor patriarcatus digestus, III (Paris 1740, posthumous edition) 525-6: 'Hunc in minoribus agentem Lutetiae Parisiorum multi viderunt, virum apprimè doctum \& humanissimum, suavissimaque indole omnibus acceptissimum [...]. Ei autem multiplici nomine obnoxium me profiteor, verba sunt $\mathrm{P}$. le Quien auctoris hujus operis'. An original letter from Lequien to Chrysanthos, dated 5 October 1720, is also preserved in the Bibliothèque nationale de France [= BnF], Paris, Suppl. gr. 1093 [Diktyon (Réseau numérique pour les manuscrits grecs) 53757], f. 66r-v.

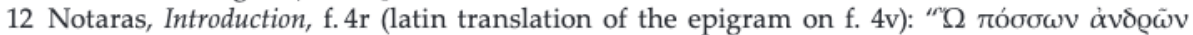

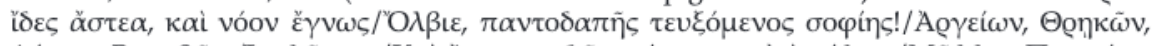

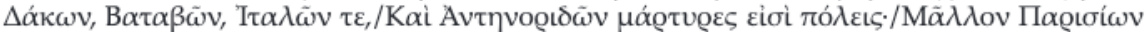

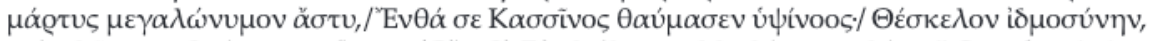

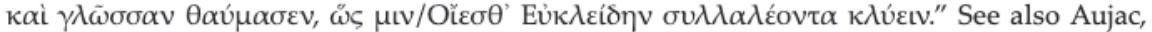
'Deux manuels', 72. It should be noted that Chrysanthos himself wrote a commentary on Euclid while in Padua, between April and November 1698. It is kept in the autograph, $\mathrm{Na}$ tional Library of Greece [= NLG], fonds of Metochion Panagiou Tafou [Metochion of the Holy

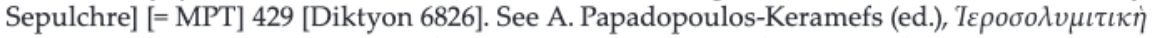

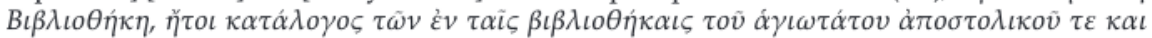

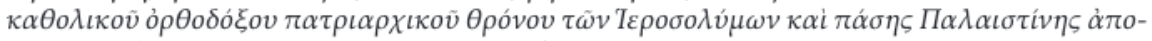
$\kappa \varepsilon \iota \mu \varepsilon \dot{\varepsilon} \nu \omega v \dot{\varepsilon} \lambda \lambda \eta v \iota \kappa \tilde{\omega} v \kappa \omega \delta i \kappa \omega v$, IV (St Petersburg 1899) 407. 
graphie universelle. Relying on them, but also on a brief and general allusion by Dimitrios Prokopiou ${ }^{13}$, he described Chrysanthos' trip as follows:

He travelled in almost all learned Europe to increase his knowledge. He spent a rather long time in Paris, where he perfected himself in the study of astronomy, ardently following the lessons of the celebrated Cassini, who regarded him as one of his best pupils, and had a special esteem for him. Chrysanthos attracted the friendship of almost all the men of the capital who were the most distinguished in the sciences. He was intimately bound up with Father Lequien, to whom he provided abundant materials for the composition of his Oriens christianus. ${ }^{14}$

Unfortunately, Nicolopoulo's elaborations gave rise to the widely held opinion that the archimandrite went on to study with Cassini, followed his path, and disseminated later the new science in the East. ${ }^{15}$ However, as suggested by Pinelopi Stathi, ${ }^{16}$ this interpretation must be relativised: Chrysanthos did not study in Paris. On the one hand, he himself talks of a single week spent at the Observatory, giving the impression of having been received as a distinguished guest, rather than a student-an interpretation enhanced by the tone of the epigram; and on the other hand, after 20 July 1700, Cassini was no longer in the capital: he had left on his grand 'Voyage de la Méridienne' which was to continue until December of the same year. ${ }^{17}$

Moreover, it is difficult to imagine that Chrysanthos stayed on in Paris at the very moment when the issue of the Holy Places was fiercely disputed in Constantinople under the impulse of Patriarch Dositheos, as part of the Russian-Ottoman peace treaty of July 1700. As an immediate consequence of this affair, Chrysanthos' presence is attested in Constantinople, ${ }^{18}$ and then in Walachia in the autumn of $1700 .{ }^{19}$ As early as 5 January 1701 he arrives in Russia, where he acts as envoy

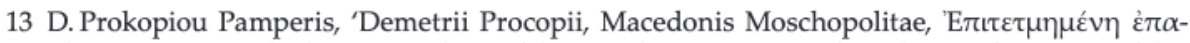

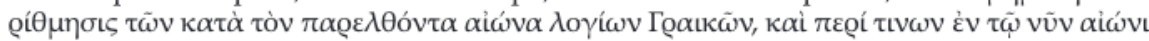
$\dot{\alpha} v \theta o u ́ v \tau \omega v$. Succinta Eruditorum Graecorum superioris et praesentis saeculi recensio, conscripta mense Junio A.C. MDCCXX transmissaque Bucuresto, et nunc primum edita, cum Latina versione', in J. A. Fabricius (ed.), Bibliotheca Graeca, XI (Hamburg 1722) 792-3: Chrysan-

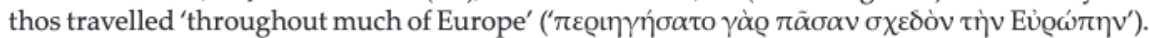

14 [Constantin-Agathophron Nicolopoulo], 'Notaras (Chrysanthe)', in L.-G. Michaud (ed.), Biographie universelle, ancienne et moderne ... , XXXI (Paris 1822) 404-5 (my translation).

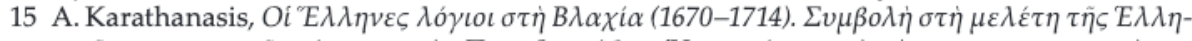

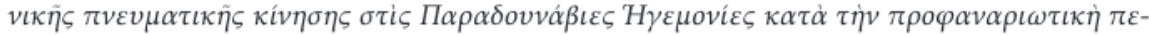

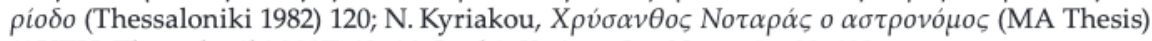

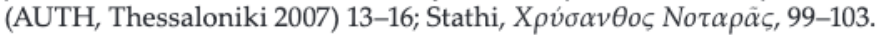

16 Ibid., 89 .

17 The diary of this trip written by Jacques Cassini has been preserved: Bibliothèque de l'Observatoire de Paris $[=B O P]$, D2/39, https://bibnum.obspm.fr/ark:/11287/mTWrq. See also L. Gallois, 'L'Académie des Sciences et les origines de la carte de Cassini', Annales de Géographie 99 (1909) 193-204; 100 (1909) 297-8 [Gallois gives the date of 20 August, which seems erroneous].

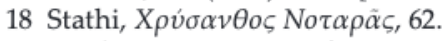

19 Vasiliu, 'Costantino Brâncoveanu', 116. 
of his uncle, bearing letters to the Tsar in favour of the patriarchate of Jerusalem. ${ }^{20}$ On 18 March 1701 he is still in Moscow. ${ }^{21}$ And finally, on 6 April 1702, he is back in Jerusalem, where he is ordained metropolitan of Cesarea in the church of the Anastasis. It appears therefore that his stay in Paris lasted no more than two or three months.

\section{The glorious return}

If the Paris trip can hardly be considered as part of a study tour, nevertheless Chrysanthos' visit to the Observatory impressed his contemporaries more than all his other activities in the West. In fact, after his return, the archimandrite was considered a great connoisseur and purveyor of astronomical instruments and geographical tools in the erudite circles of the Ottoman Empire. He himself mentions a 'precisely divided, one-foot long quadrant' purchased by him in Paris and which permitted him to revise the measurement of degrees of longitude and latitude in his 'own convent in Constantinople', i.e. the Metochion of the Holy Sepulchre. ${ }^{22}$ In the secondary literature there is also the mention of an astrolabe. According to a late account, the archimandrite had constructed it in Paris and had brought it back to the East. Found in 1892 in Jerusalem but later destroyed, this astrolabe bore the following inscription: 'This instrument was built by the monk Chrysanthos under the direction of Cassini for the brothers of Jerusalem, so that they might worship the Lord through His works. ${ }^{23}$ It probably belonged to a whole batch of tools reported in the inventory of the school of the monastery of the Holy Cross around 1895:

At that time it was not only a large number of useless books that were thrown into the monastery's ovens, but also various geographical spheres, which had been consecrated [to the patriarchal institution] by Chrysanthos Notaras, Patriarch of Jerusalem, as well as large geographical maps repre-

20 The date appears in a Russian archival document: Russian State Archive of Early Acts (= RGA$D A), 52-1,1701$, no. 2, 105ff. See I. I. Bantyš-Kamenskij, Reestry grečeskim delam Moskovskogo Arkhiva Kollegii inostrannykh del. Rossijskij Gosudarstvennyj arkhiv drevnikh aktov. Fond 52. Opis' 1, B.L. Fonkič (ed.) [Rossia i Khristianskij Vostok. Biblioteka, 2] (Moscow 2001) 226. See also M. M. Bernacki, 'Dosifej II Notara, Patriarkh Ierusalimskij', in Pravoslavnaia Enciklopediia, vol. XVI (Moscow 2007) 71-7, here p. 74.

21 Vasiliu, 'Costantino Brâncoveanu', 114; N. Nilles, Symbolae ad illustrandam historiam ecclesiae orientalis in Terris coronae S. Stephani, I (EEniponte [= Innsbruck] 1885) 101-3, here p. 102.

22 This information appears in the following statement of longitude and latitude recorded by Notaras, Introduction, 165, sub verbo 'Buל̌́x

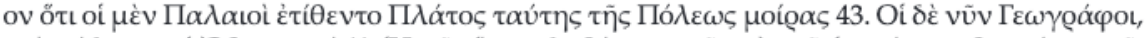

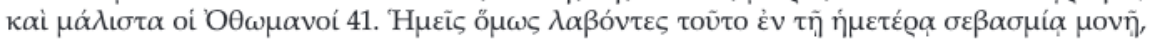

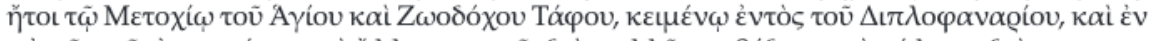

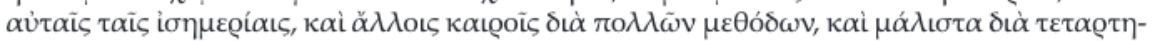

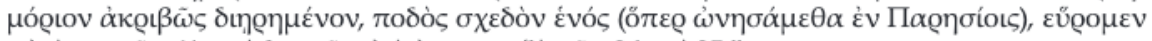

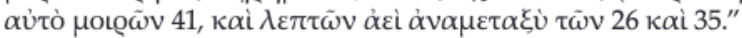

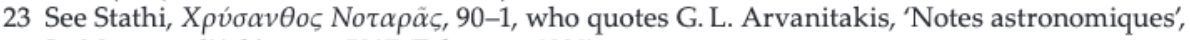
Le Messager d'Athènes, n. 5217 (February 1939). 
senting each people of the countries of Europe, Asia, Africa, America and Polynesia, painted with bright and indelible colours, which had become useless because of the mould, and so have been thrown into the fire. As for the astronomical and mathematical instruments used by the late Chrysanthos, Patriarch of Jerusalem, all of them were destroyed because of the rust. Only one or two of them are [still] kept in the library of the Theological School, in memory of the late Chrysanthos, the excellent mathematician of that time. [In note:] It must be remarked that in the library of the Metochion of the Holy Sepulchre in Constantinople are also preserved in a box a considerable number of astronomical instruments, which were used by the late Chrysanthos. But these too are rusty. ${ }^{24}$

Hence, it appears that Chrysanthos had progressively constituted, in Jerusalem as well as in Constantinople, an important collection of scientific instruments which corresponded to his specific interest in mathematics, astronomy and geography. Until it was completely destroyed this collection impressed posterity and perpetuated his name as that of an immensely skilled and enlightened man. Thus, he was solicited on all sides. A correspondent from Chios asked him for instructions when he intended to build an astrolabe. ${ }^{25}$ On 26 February 1713, the Prince of Moldavia, Nikolaos Mavrokordatos, wrote to him: 'We received also the telescope and we thank Your Beatitude for it. ${ }^{26}$ On 11 November 1716, Chrysanthos was the posthumous dedicatee of a manuscript of Meletios Mitros' Geography Old and New. ${ }^{27}$ The Ottoman scholar Esad Efendi, who had ties of trust and friendship with Chry-

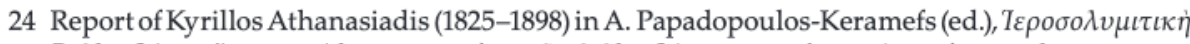

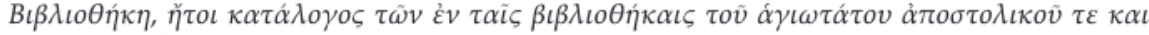

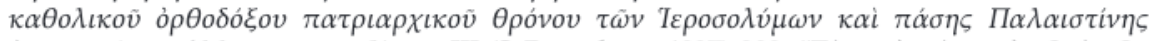

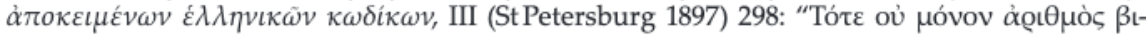

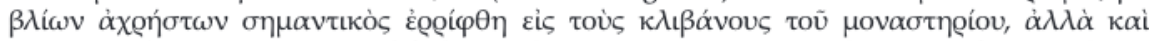

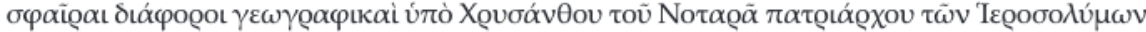

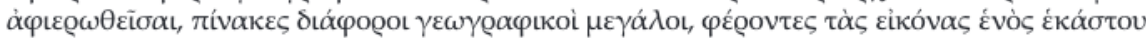

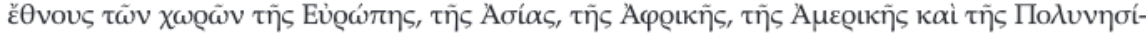

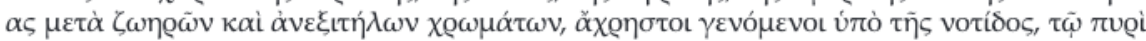

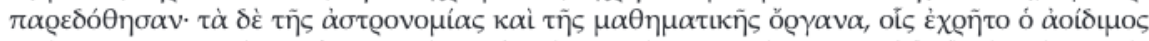

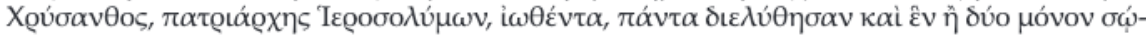

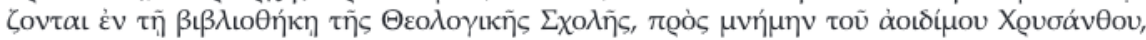

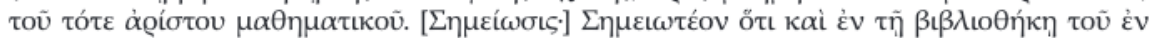

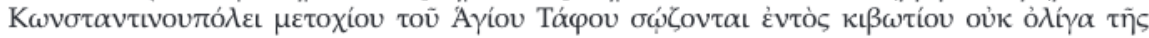

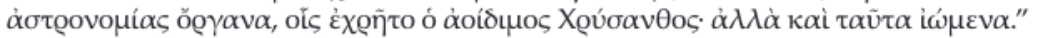

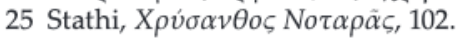

26 E. Hurmuzaki (ed.), Documente privitoare la istoria Românilor, XIV/I. 1320-1716: Documente Gre-

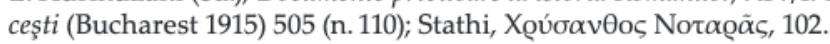

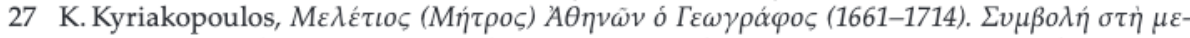

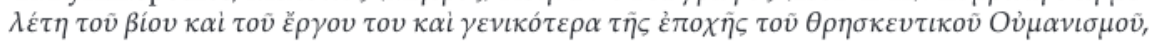
2 vols (PhD Thesis) (National and Kapodistrian University of Athens, Athens 1990) 186-98. Already started in 1707, Meletios' publication project was not completed during his lifetime, and the book came out only in 1728, in Venice. Aside from the NLG, MPT 241 [Diktyon 6638], which contained the Geography Old and New, Chrysanthos had also in his library a copy of the 
santhos, and also his master Ali Efendi, the Porte's astrologer ('münecimbaşi'), corresponded with him on various astronomical subjects. ${ }^{28}$

Moreover, the archimandrite's best-known portrait shows him with his left hand on a globe and the right holding a compass-in a similar way to that in which Cassini and other Western scientists and explorers were depicted at the time..$^{29}$ This engraving appeared on the frontispiece of the Introduction to Geographics and Sphaerics, when Chrysanthos was already patriarch of Jerusalem. And although this portrait was obviously drawn many years before its publication, when he was still travelling in the West, ${ }^{30}$ the fact remains that the image it presentedthe young Chrysanthos as an astronomer and a geographer ${ }^{31}$-was still important enough to illustrate the patriarch's book.

Finally, let us add this crucial information: on his return, Chrysanthos was not only regarded as an excellent scientist, but also as a man faithful to the Orthodox tradition. This is clearly shown in a particularly interesting letter sent to him by Alexandros Mavrokordatos in the year 1702 or later:

Of your peregrinations in Europe and in the countries and cities which are there I admire nothing more than your return, for your progress and your achievements have not altered or falsified your manners or your convictions. Those who choose to leave and to travel have much to gain from knowing the cities and minds of the multitude [...]. But I have often becried and mourned those who [...] defiled their thoughts with degenerate doctrines [...]. Even if they were not shipwrecked during their journey, they have not been less affected by this terrible sinking of their manners and their souls on dry land. As for you, very learned man, thanks to God in His excellence, you have preserved [your soul] [...] and you have returned from this trip by having obtained great benefits [...]. As a bee who loves

Astronomical Book, written in 1700, by the same Meletios, namely the NLG, MPT 420 [Diktyon

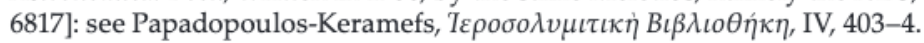

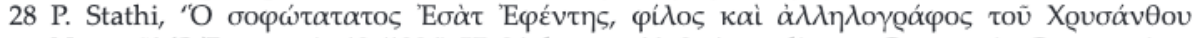

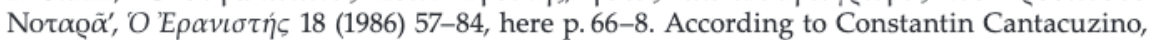
Ali Efendi 'lost the rules of astrology by seeing the confusion of the movement of the stars'

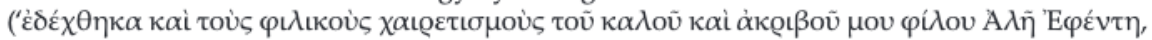

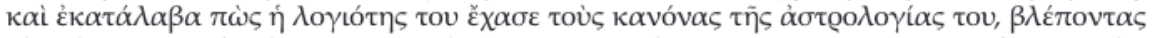

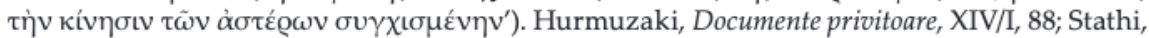

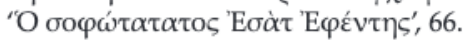

29 See for instance the engraving of Louis Cossin, Portrait de J. D. Cassini, en buste, de 3/4 dirigé à gauche (Paris 1712), https://catalogue.bnf.fr/ark:/12148/cb41506294n. Since 1578, Ptolemy was also represented with a compass and two globes. J.-M. Besse, 'Le regard du cosmographe', in C. Hofmann and Fr. Nawrocki (eds), Le monde en sphères (Paris 2019) 118-23, here p. 122.

30 The engraving bears an epigram with the initials 'N. B.' corresponding to Nikolaos Vouvou-

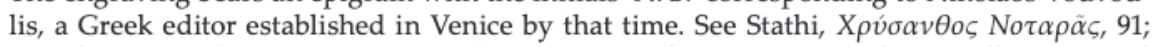

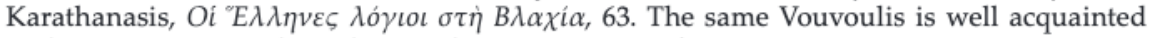
with Komninos-Papadopoulos. Vasiliu, 'Costantino Brâncoveanu', 114-5.

31 On the front page of Chrysanthos' Introduction, there is an engraving with two globes representing Astronomy and Geography. 
the effort, you have drawn pure honey from the science of those very bitter flowers. $^{32}$

\section{Chrysanthos before visiting Paris: a distinguished scientist fostered by Protestant and Catholic networks}

Chrysanthos' scientific interests in the years 1680-1693

Even if Chrysanthos did not study in Paris and if, moreover, he resisted the siren calls of the West, does this mean that his visit to the Observatory was the result of simple curiosity, or that it was merely a fashionable attraction offered to the nephew of a powerful hierarch from the Christian East? ${ }^{33}$ In my opinion, this is not the case. On the contrary, I believe-and this is what I wish to explore in this paperthat in 1700 the man of whom François Sevin later said that 'the Greeks regard him as the most learned figure of his century ${ }^{\prime 34}$, already possessed solid knowledge in the field of modern science, and particularly in astronomy and geography, two closely related disciplines.

We do not know the date of Chrysanthos' birth, nor that of his arrival at Constantinople. However, it can be assumed that in 1680, when he adorned the man-

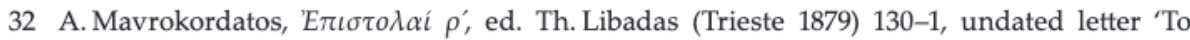

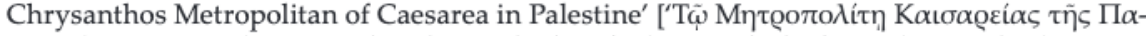

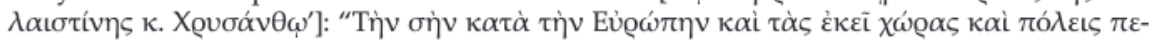

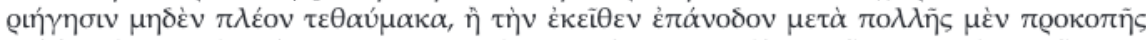

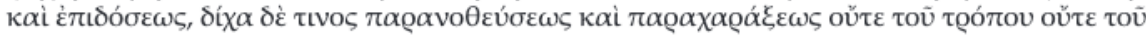

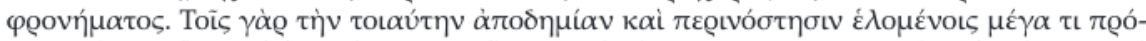

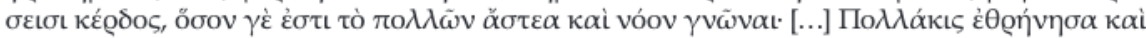

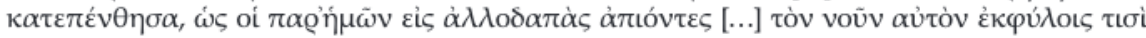

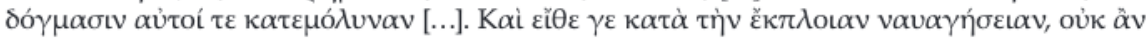

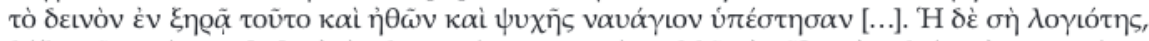

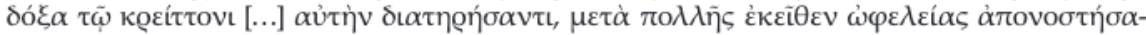

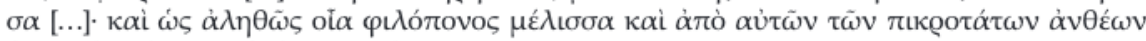

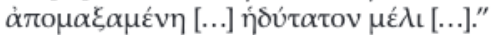

33 In the 17th century, the Observatory with its 'machines' was a place that the Court attended as an attraction, and where many personalities and their families were welcomed. These social activities, known as 'passion des astres', are well documented by Cassini, who himself acted as a courtier. See, for instance G. Picolet, 'Une visite du jeune Saint-Simon à l'Observatoire de Paris', Cahiers Saint-Simon 26 (1988) 59-68. Cassini's taste for the Court, and the doubtful scientific choices that sometimes resulted from it, were heavily criticized in the nineteenth century for 'having stopped the progress of science'. See R. Radau, 'L'Observatoire de Paris depuis sa fondation', Revue des Deux Mondes [2nd Period] 73 (1868) 740-68, who considers the French observatory as 'un édifice de parade' (ibid., 744).

34 Letter of François Sevin to Maurepas (Constantinople, 16 April 1729) in H. Omont (ed.), Missions archéologiques françaises en Orient aux XVII et XVIII" siècles, I (Paris 1902) 469: "Le Patriarche me donna parole positive, non seulement de me montrer sa bibliothèque, lorsque sa santé seroit rétablie, mais encore de m'aider de tout son crédit. Il en a beaucoup en ce pays cy, les Grecs le regardent comme le plus sçavant personnage de son siècle ; ils ont tort, et je puis vous assurer que jamais connoissances ne furent plus superficielles ; c'est un petit homme plein de feu et très simple, quant à l'extérieur, mais qui, sous ses dehors de simplicité, cache bien de l'esprit et du manège. [...] Deux métropolites vinrent avant-hier m'apporter de sa part un traité de géographie qu'il a publié autrefois." 
uscript MPT 261 [Diktyon 6658] with a possessor's note, he was more than twenty years old ${ }^{35}$ and had studied rhetoric. A year later, in 1681, his teacher at the Patriarchal Academy was Sevastos Kyminitis from Trebizond; Kyminitis taught him Aristotelian philosophy, and especially the Topics. This teaching drew on the commentaries of the radical Neo-Aristotelian Theofilos Korydallefs, a disciple of Cesare Cremonini in Padua and a defender of both geocentrism and the total emancipation of philosophy vis-à-vis scholasticism. Indeed, among the manuscripts owned by Chrysanthos at the time was also the manuscript MPT 121 [Diktyon 6518], containing Korydallefs' commentary on the Geography of Ptolemy [ $\Gamma \varepsilon \omega \gamma \rho \alpha-$ $\varphi \iota \kappa \dot{v} \dot{\varphi} \eta \dot{\gamma} \eta \sigma \iota \varsigma]$.

However, the scientific curiosity of the young Chrysanthos goes beyond the framework of Neo-Aristotelianism. Encouraged by his masters in Constantinople or by his own reading of manuscripts, he undertook to broaden his astronomical knowledge by exploring the Arab and Byzantine traditions which themselves had relied since the thirteenth century on Persian astronomy from the Maragha School. ${ }^{36}$ Thus, in the same manuscript, MPT 121 [Diktyon 6518], Chrysanthos copied Isaac Argyros' Treatise on the Astrolabe and, in MPT 198 [Diktyon 6595], the Greek translation of an astronomical book by Abu Ma'shar. Finally, in the early 1680s, he began writing an Explanation and description of the quarter of the sphere, called rup-dagire in Arabic, a text preserved in the manuscript MPT 200 [Diktyon 6597] and which attracted great attention. ${ }^{37}$ But of course, all these astronomical and geographical concepts were not disrupted by modern science, even if Galileo was teaching in Padua when Korydallefs was studying there. ${ }^{38}$

According to recent research, Chrysanthos' traditional beliefs in the field of Astronomy were dispelled during his trip to Moscow in 1692, after the reading of a Compendium historicum de Astronomia apud Sinas addressed to Alexis I Mikhailovich (1645-1676) by the Jesuit astronomer and missionary Ferdinand Verbiest. In

35 According to the Holy Canons, since he was an archdeacon by that time, he should have been more than twenty-five years old. One can ask, however, if the canonical order was strictly followed.

36 See G. Saliba, 'The role of Maragha in the development of Islamic Astronomy: a scientific revolution before the Renaissance', Revue de synthèse 4/3-4 (1987) 361-73; G. Saliba, 'Revisiting the astronomical contacts between the World of Islam and Renaissance Europe: the Byzantine connection', in P. Magdalino and M. Mavroudi (eds), The Occult Sciences in Byzantium (Geneva 2006) 361-74; E. Nicolaidis, Science and Eastern Orthodoxy. From the Greek Fathers to the Age of Globalization, transl. Susan Emanuel (Baltimore MD 2011) 106-18.

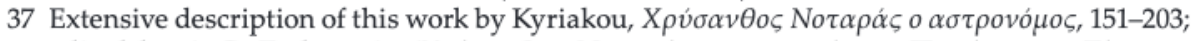

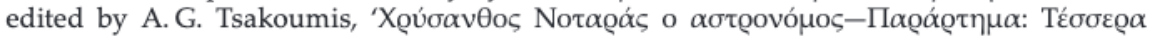

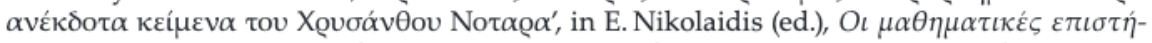

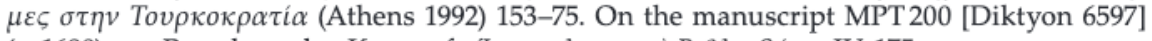

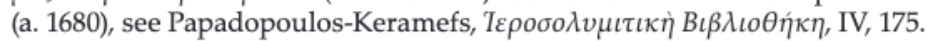

$38 \mathrm{Cl}$. Tsourkas, Les débuts de l'enseignement philosophique dans les Balkans. La vie et l'auvre de Théophile Corydalée (1570-1646) (Thessaloniki 1967) 35-44, reports that Korydallefs was proclaimed doctor of the University of Padua in 1613 and supposes that he began his studies there in 1607. Galileo taught in the same University from 1592 to 1610. 
1677-1678, this text had been brought from China by Nicolas Spathar Milescu, a Greek born in Moldavia and appointed to the service of the Tsar. ${ }^{39}$

When he arrived in Beijing in 1676 for a round of negotiations between the two empires, Spathar Milescu was received by Verbiest who held the position of head of the Mathematical Board and director of the Observatory. Appointed to this prestigious position as a result of a long and violent controversy which opposed him to Chinese astronomers, the Jesuit had managed to impose his scientific theories, which were completely new in the Far East. In particular, he had convinced the young Emperor K'ang-hsi (1661-1722) of the accuracy of his observations on the calendar. His methods, and also the new instruments he installed at the Beijing Observatory, in the end won the approval of all the court astronomers. ${ }^{40} \mathrm{In}$ welcoming Milescu, and acting himself as a mediator between the Tsar's ambassador and the Chinese Emperor, Verbiest willingly preserved the interests of the Jesuits; but he also took advantage of his position and tried to suggest to the Tsar a reform of the Julian calendar. He therefore composed for him the small Compendium, which he completed with engravings representing the new instruments of the Observatory of Beijing. However, when Spathar came back to Moscow, Alexis I was already dead, and it is not known if the document was ever handed over to his successor. Its pro-Jesuit content and proposal of reform had certainly upset the ambassador, and he may have withheld the treatise.

In 1689, the Patriarch Dositheos-whose anti-Latinism is well known-contacted Spathar. ${ }^{41}$ He questioned him extensively about China, and finally sent his nephew to him. In Moscow, Chrysanthos had close contact with Milescu, who allowed him to copy Verbiest's manuscript, and gave him also an account of his own trip. ${ }^{42}$ In 1693, when he returned to Constantinople, Chrysanthos brought these documents with him. According to Euthymios Nikolaïdis, the archimandrite's discovery of 'Jesuit science ${ }^{43}$ through this amazing detour inspired him to undertake studies at Padua in his mature years:

39 Ferdinand Verbiest, Magno Principi Tsari et Magno Duci Alexio Michaelovicz, Compendium historicum de Astronomia apud Sinas restituta ..., anno Christi MDCLXXVI. To date, only one copy of this treatise is known, the manuscript MPT 423 [Diktyon 6820] brought by Chrysanthos from

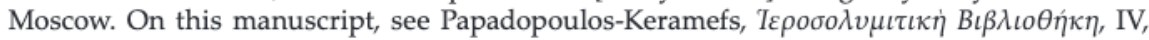
405, reconsidered by E. Nikolaidis, 'Verbiest, Spathar and Chrysanthos. The spread of Verbiest's science to Eastern Europe', in W. F. Vande Walle and N. Golvers (eds), The History of the Relations between the Low Countries and China in the Qing Era (1644-1911) (Leuven 2003) 37-57, here p. 51. Also N. Golvers and E. Nicolaidis, Ferdinand Verbiest and Jesuit science in 17th century China: an annotated edition and translation of the Constantinople manuscript (1676) (Athens-Leuven 2009).

40 On this affair, see Pingyi Chu, 'Scientific dispute in the Imperial Court: the 1664 calendar case', Chinese Science 14 (1997) 7-34.

41 Letter of Dositheos to Milescu, in E. Legrand (ed.), Bibliothèque grecque vulgaire, III (Paris 1881) xxxv.

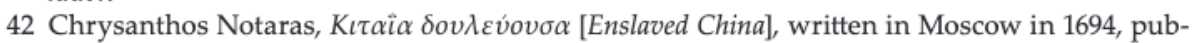

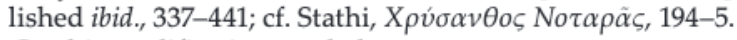

43 On this qualification, see below. 
The copy made for Chrysanthos introduced him to a new world. The presentation of Verbiest's science provided by this text was extremely important for Chrysanthos' scientific future. This was an encounter with 'another' science, and it provided Chrysanthos with a strong motivation to study the 'new knowledge'. Immediately after his sojourn in Moscow, in 1697, he travelled to Italy [...]. Here, he found books and teaching more up-to-date than those provided by Verbiest's manuscripts. With respect to astronomy, three years later, in 1700, he visited the most modern and scientifically important institution of that time, the Observatory of Paris [...]. The spread of the new astronomy to Eastern Europe and the Ottoman Empire begins after that date, and Chrysanthos' encounter with Verbiest's astronomy was the first important contact between Greek scholars and the new European science, which, in this case, came from China through Russia. ${ }^{44}$

Even if Chrysanthos' fascination with the instruments of the Beijing Observatory as described and illustrated by Verbiest was genuine, new evidence allows us to relativize this narrative and to affirm that the archimandrite already had a certain knowledge of modern science before 1692. But in this case, he gained access to it not through Catholic networks, but through Protestant-and especially Anglican-channels.

\section{An extraordinary order}

According to the correspondence between Dositheos and John Covel, chaplain to the Levant Company in Constantinople in the years 1670 to 1676, and Master of Cambridge in the long period of 1688-1722, a very impressive order related to Chrysanthos' scientific interests was made in November 1689 and supplemented in January 1690. It is clearly attested by a letter preserved in the manuscript of the British Library, Harley 6943 (1672-1711) [Diktyon 39727], f. 89r-v, and included in a larger folder (f. $89 \mathrm{r}-92 \mathrm{v}$ ), to which a specific study should be undertaken. This exchange, which is to be found in the Appendix, occurs between a certain number of actors as follows:

On 9 October $1684,{ }^{45}$ while Europe was torn apart and communication between the Ottoman Empire and Western countries became extremely difficult, Thomas Coke, ${ }^{46}$ secretary of the Levant Company for several decades and chancellor of the British Residency in Constantinople, wrote a letter to John Covel informing him of an exchange he had had with the patriarch Dositheos. In fact, the three men knew one another, and had perhaps met while Covel was still in the East. ${ }^{47}$ In his letter,

44 Nikolaidis, 'Verbiest, Spathar and Chrysanthos', 57.

45 Appendix, I.

46 On him, see J.-P. Ghobrial, The Whispers of Cities. Information Flows in Istanbul, London, and Paris in the Age of William Trumbull (Oxford 2013) especially p. 137-42.

47 Covel and Dositheos had met in Adrianople, in 1675. See V. Kontouma, 'Christianisme orthodoxe. Recherches sur Dosithée II de Jérusalem (1669-1707)', Annuaire de l'École pratique des 
Coke gives the following information: around March 1684, Ioannakis Porfyritis ${ }^{48}$ had contacted him and had given him a book from Dositheos. Intended for Covel, the book was immediately sent to England, but Coke had received no reply. So, another book was to be sent. Given by Dositheos himself, it was a work of Nektarios of Jerusalem dealing with the Pope's primacy. ${ }^{49}$ The dispatch was made through Mr. Barclay, an employee of the Resident.

Five years later, on 2 November $1689,,^{50}$ Covel had still not responded, but Coke wrote to him again, encouraged by Mr. Gerard, an otherwise unknown person who gave him news of the Master's promotion, probably to Vice Chancellor of Cambridge. In fact, Coke had had another encounter with Dositheos. The latter gave him two books for Covel: 'Nektarios', which had been sent earlier but was supposed to have been lost, and 'Symeon' printed in 1683 in Iași. ${ }^{51}$ This time, however, Dositheos did not simply send presents. He also wanted to place a very precise order, transmitted by Coke.

This order, which is extraordinary in respect of its size and the value of the items requested, is divided into two lots. First, there is a series of books published in the West, including 'all the Byzantine Historians' of La Byzantine du Louvre, a luxury collection patronized by Louis XIV. ${ }^{52}$ Other titles are detailed in an autograph list written by Dositheos ${ }^{53}$ and attached to Coke's letter. The patriarch stress-

hautes études 124 (2015-2016) 207-18, here p. 216-17. It is likely that Coke was part of the same British delegation to Adrianople in which most of the Residency seems to have participated in 1675.

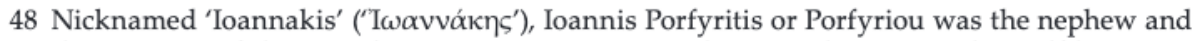
the assistant of the Grand Dragoman Panagiotis Nikousios (d. 1673). He himself became a dragoman in the service of Austria, then of the Porte. He belonged to the circle of close collaborators of Patriarch Dositheos. For more on Porfyritis, see B. Sfyroeras, Oi $\Delta \rho \alpha \gamma o v \mu \alpha$ voo

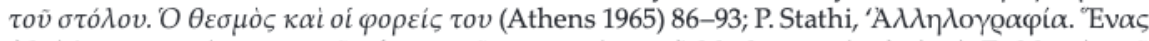

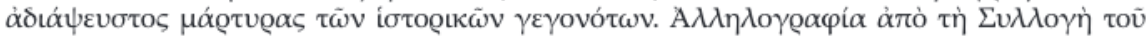

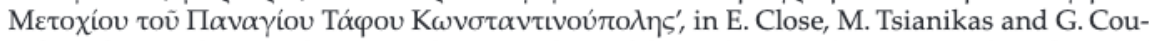
valis (eds), Greek Research in Australia: Proceedings of the Sixth Biennial International Conference of Greek Studies, Flinders University June 2005 (Adelaide 2007) 389-400, here p. 394-5.

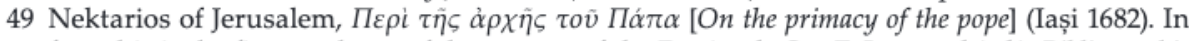
fact, this is the first work out of the presses of the Patriarch. See E. Legrand (ed.), Bibliographie hellénique ou description raisonnée des ouvrages publiés par des Grecs au dix-septième siècle, II (Paris 1894) 568; K.-P. Todt, 'Dositheos II. von Jerusalem', in C. G. Conticello and V. Conticello (eds), La théologie byzantine et sa tradition, II (XIII $-X I X^{e}$ s.) (Turnhout 2002) 659-720, here p. 670; F. Gabriel, 'Tradition orientale et Vera Ecclesia : une critique hiérosolymitaine de la primauté pontificale. Nektarios, de Jassy à Londres (v. 1671-1702)', in M.-H. Blanchet and F. Gabriel (eds), Réduire le Schisme ? Ecclésiologies et politiques de l'union entre Orient et Occident (XIII ${ }^{e}-\mathrm{XVIII}{ }^{e}$ siècle) (Paris 2013) 197-236.

50 Appendix, II.

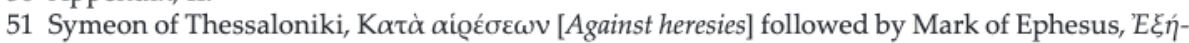

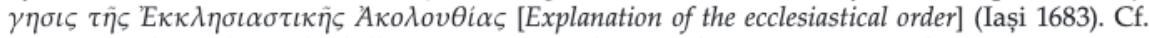
Legrand (ed.), Bibliographie hellénique, II, 578; Todt, 'Dositheos II. von Jerusalem', 670-1.

52 See N. Petit, 'La Byzantine du Louvre', in M.-F. Auzépy and J.-P. Grélois (eds), Byzance retrouvée. Érudits et voyageurs français (XVI'-XVIII siècles). Catalogue de l'exposition. Chapelle de la Sorbonne, Paris, 13 août-2 septembre 2001 (Paris 2001) 70-80 and 81-4.

53 Appendix, IV. 
es that the works must be in Greek or in a bilingual Greek-Latin version. Books in Latin alone do not suit him, as he does not read this language. Second, Coke's letter refers to a series of maps and geographic and astronomical instruments, as well as a series of Commentaries on Aristotle. This batch is not mentioned in the autograph list. ${ }^{54}$ It seems to correspond to an oral request made by the Patriarch and his relatives-Coke once says 'they' instead of 'he'-and, in this case, Latin is not a problem. We can also add that the content of the order is not related to Dositheos' interests, but rather to the concerns of his nephew Chrysanthos, already a connoisseur of Arab-Byzantine astronomy by that time. The exact content of the second lot is detailed in Coke's letter:

He desires also a paire of Globes of about 14 inches diameter, and a paire of small globes about the bignesse of one's fist for to carry easily in a journey, and 4 Maps of the foure parts of the world, but these all in Latin, and not in English. They desire the Globes may have two Poles, and the brasse circle to remove from one to the other. He desires also, all the Greeke Comentators on Aristotles Metaphysics, as Alexander, Themistius, Ammonius, and The bookes must bee carefully packt up, that they bee not damaged, and especially the Globes, that they bee not broken. ${ }^{55}$

Coke also states that the order will be paid through Thomas Palmer, merchant of the Levant Company. He does not say, however, whether the Company advances the money, or whether it fully bears the costs, as a tribute to the patriarch.

The exchange continues on 14 January $1690,{ }^{56}$ as Coke, fearing that his letter has again gone missing, sends a duplicate of it. He also adds to the order the Geographical Dictionary of Filippo Ferrari ${ }^{57}$ presumably requested by Chrysanthos in the meantime. Finally, in March 1690, ${ }^{58}$ Thomas Palmer contacts Covel from London for payment of the purchases, announcing that the parcels will leave England within a period of twelve months.

It seems that the order was sent within this deadline, and that it arrived safely. Indeed, Covel notes on the back of Palmer's letter: 'He will pay me for the patriarch's books', ${ }^{59}$ a sign that he was preparing to insure the purchases. Moreover, many of the books ordered by the Patriarch appear in the first inventory of the Metochion library. ${ }^{60}$ But why did the Master of Cambridge agree to attend to such

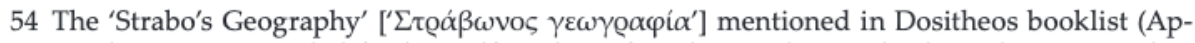
pendix, IV) is intended for himself, and not for Chrysanthos. Indeed, Strabo is quoted in Dositheos' History.

55 Appendix, II, first part.

56 Appendix, II, second part.

57 Philippus Ferrarius, Lexicon Geographicum, ed. William Dillingham (London 1657); 2nd ed. Michel Antoine Baudrand (Paris 1670).

58 Appendix, III.

59 Appendix, III.

60 This research is currently in progress. On the inventory of manuscripts and printed books of the Metochion Library (NLG, MPT 93 [Diktyon 6490]), which was compiled at the death of 
a large and cumbersome order? Obviously, this is related to the very special relationship he had with Dositheos. Since they had met at Adrianople in 1675, the two men had been in frequent correspondence. Dositheos gave the Englishman some manuscripts, and Covel had begun to translate into Latin the treatise On the Primacy of the Pope by Nektarios, a translation which he dedicated to the patriarch in $1685,{ }^{61}$ calling for empathy 'between the Eastern Church and the British Church', ${ }^{62}$ and hoping that the Orthodox would endorse the Anglican point of view. As for Dositheos, he was concerned with the publication and distribution of some fiercely anti-Catholic books, a project for which he expected the support of Protestant networks, if not outright funding by the Levant Company.

Because of the difficulties of navigation, ${ }^{63}$ it appears that the long-awaited order did not arrive in Constantinople until the summer of 1692. In 1689, Dositheos had probably thought that it would be a good gift for his nephew, who was about to be ordained. But Chrysanthos received it three years later, and it is unclear whether he could really make use of it, since he was preparing to leave for Russia. However, in 1689 Chrysanthos knew exactly what he wanted. Among other things, he knew the size and characteristics of the globes: by this time, he had already seen and used such objects. This need not surprise us. In 1688, he had travelled to Berlin and Poland, where he had certainly had his first contacts with the new science. Even in Constantinople, and when travelling by sea to Jerusalem or the Black Sea, he must have seen on ships of the Levant Companies the terrestrial and celestial globes commonly used for navigation. ${ }^{64}$ Last but not least, the archimandrite frequented the Wallachian court of Constantin Brâncoveanu, where the interest in astronomy and geography seems to have been as great as his own..$^{65}$

\section{Astronomy and cartography at the Wallachian court}

Since Ptolemy, a number of distinct sciences-mathematics, astronomy and geography-converged to form the single discipline of cosmography. The Christians had included this in theology, perceiving the universe as created. In rediscovering Ptolemy in the fifteenth century, and by laying the foundations of the scientific

Chrysanthos in 1731, see A. Lampadaridi, 'La bibliothèque du Métochion du Saint-Sépulcre à Constantinople à travers ses inventaires anciens', in A. Binggeli, M. Cassin, M. Detoraki and A. Lampadaridi (eds), Bibliothèques grecques dans l'Empire ottoman (Leuven 2020) 291-310.

61 V. Kontouma, 'Christianisme orthodoxe. Recherches sur Dosithée II de Jérusalem (suite)', Annuaire de l'École pratique des hautes études 125 (2016-2017) 251-5, here p. 253.

62 V. Kontouma, 'Recherches sur Dosithée II de Jérusalem', 217-8 (text from the manuscript Brit-

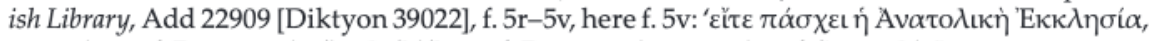

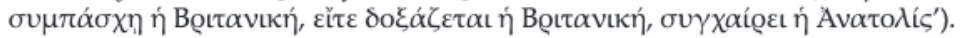

63 On the difficulties faced by British ships in this period, see E. D. Tappe, 'Documents concerning Rumania in the Paget papers', The Slavonic and East European Review 33/80 (December 1954) 201-11.

64 P. Van der Krogt, 'L'usage des globes dans la société européenne aux XVI $-X V I I{ }^{e}$ siècles', in C. Hofmann and Fr. Nawrocki (eds), Le monde en sphères (Paris 2019) 144-50.

65 Chrysanthos was active in this circle for long periods (1684; 1687, 1688; 1689/90; 1693-1696;

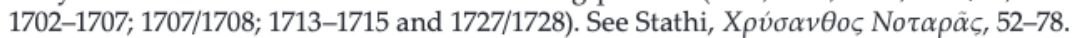


revolution, the West did not depart from this world-view. ${ }^{66}$ On the contrary, progress in mathematics led to progress in astronomy, the latter brought about a new approach to geography, and this in turn opened new possibilities for navigation. ${ }^{67}$ Conversely, explorations facilitated not only progress in geography, but also in astronomy. Cassini clearly explains this in his essay De l'origine et $d u$ progrès de l'astronomie et de son usage dans la géographie et dans la navigation, published in 1693:

The main purpose that the Academy has set for itself in astronomical observations has always been to apply them to the advancement of Geography and Navigation. And for this purpose, nothing was more useful than to determine what part of the circumference of the earth corresponds precisely to a celestial degree. [...] After having determined the magnitude of a degree of the circumference of the Earth, several voyages were made to establish the degrees of longitude, comparing the observations which one would make in very distant places with those made simultaneously at the Observatory. ${ }^{68}[\ldots]$ The king, having been informed of the utility drawn from the observation of the eclipses of the moons of Jupiter to establish the degrees of longitude, ordered that this method should be applied to new maps of France. Immediately the Academy sent men to make many observations of these eclipses on all the coasts of the realm, and by comparison of these observations with those made simultaneously in Paris, it was found that the modern geographers who had wanted to correct Ptolemy had drawn too far westward the Western shores of the realm [...]. Based on these clarifications we have drawn up a map of the whole known earth on the floor of a tower of the Observatory, in which we have diverged from some more modern maps by $20^{\circ}$ in longitude of the Eastern lands. And the observations of the eclipses which were made in the East Indies and in Paris confirmed this difference, something which was difficult to do without the help of celestial observations. ${ }^{69}$

66 Besse, 'Le regard du cosmographe', 118-23.

67 The measurement of meridians, on which scientists such as Picard and Cassini conducted ground-breaking research, combined astronomical observations and complex calculations. Thanks to a better calculation of degrees of longitude, this also led to the refinement of geography and, thereby, to the production of maps of unprecedented precision and accuracy. See Gallois, 'La carte de Cassini', issue 100, 297-8.

68 Jean-Dominique Cassini, 'De l'origine et du progrès de l'astronomie et de son usage dans la géographie et dans la navigation', in Recueil d'observations faites en plusieurs voyages par ordre de Sa Majesté pour perfectionner l'Astronomie et la Géographie, avec divers Traités astronomiques, par Messieurs de l'Académie Royale des Sciences (Paris 1693) 1-43, here p. 39-40 (my translation).

69 Ibid., 42 (my translation). 
In some cases, scientists sought to adhere to divine laws, something that explains the enthusiasm for Tycho Brahe's cosmological theories. ${ }^{70}$ The Jesuit astronomer Giovanni Battista Riccioli took up Brahe's theories and revised them to preserve the principle of the stillness of the earth, considered to be in accordance with Scripture. ${ }^{71}$ By resorting to the traditional distinction between astronomical hypotheses and physical reality, he allowed the hypothetical use of heliocentrism, thus relativized. Admitted by the Catholic Church, such theories legitimized the practical applications of the new astronomy. As illustrated by the case of Verbiest, this formal geocentrism gave rise to the development of a 'Jesuit science' in which astronomical observation, cartography and missionary activity were associated and supported by the 'transcontinental network of the Society of Jesus'.72

In the Orthodox East, a centre of power concerned itself with these developments: at the Wallachian court of Constantin Brâncoveanu intellectuals were interested in cosmological studies. Here, the figure of Stolnic Constantin Cantacuzino-the uncle of Brâncoveanu and the father of Rădu Cantacuzino-played a decisive role. He himself had been trained at the university of Padua in the years 1667-1669, and had maintained links of friendship there, especially with Nikolaos Komninos-Papadopoulos. In Wallachia, at Mărgineni, he had brought together a library of exceptional quality where one could find cosmological treatises. ${ }^{73} \mathrm{In}$ 1696 he received an astronomical telescope from the British Resident at Constantinople, William Paget. ${ }^{74}$ Finally, he was the dedicatee of a curious Prognostikon related to the solar eclipse of $23 / 13$ September $1699 .{ }^{75}$ Having grown up in the family environment of the Stolnic, Constantin Brâncoveanu shared his interests. He built himself a prestigious library in Hurezi and maintained friendship and correspondence with great personalities of the West, including Cardinal Giovanni Francesco Albani, who became Pope in November 1700 under the name of Clement XI. ${ }^{76}$

70 See M. P. Donato, 'Scienza e Teologia nelle Congregazioni Romane. La questione atomista, 1626-1727', in A. Romano (ed.), Rome et la science moderne. Entre Renaissance et Lumières (Rome 2008) 595-634, here p. 595.

71 F. Beretta, 'L'héliocentrisme à Rome à la fin du XVII e siècle : une affaire d'étrangers ? Aspects structurels d'un espace intellectuel', in A. Romano (ed.), Rome et la science moderne. Entre Renaissance et Lumières (Rome 2008) 531-54, here p. 547, note 80; M.-P. Lerner, 'L'entrée de Tycho Brahe chez les jésuites ou le chant du cygne de Clavius', in L. Giard (ed.), Les Jésuites à la Renaissance. Système éducatif et production du savoir (Paris 1995) 145-85.

72 A. Romano, 'L'horizon romain de la science moderne. Des sentiers à ouvrir', in A. Romano (ed.), Rome et la science moderne. Entre Renaissance et Lumières (Rome 2008) 637-59, here p. 651, note 32 (in this paper, Romano opposes Jesuit theories to those of the Dominicans, who still relied on Scholastic Aristotelianism).

73 C. Dima-Drăgan, Biblioteca unui umanist român Constantin Cantacuzino Stolnicul (Bucharest 1967) 68-70; C. Dima-Drăgan and M. Carataşu, 'Un manuscrit inédit du Docteur Jean Comnène', Revue d'études sud-est européennes 11 (1971) 107-20, here p. 112-13, note 5.

74 Tappe, 'Documents concerning Rumania in the Paget papers', 202; Dima-Drăgan and M. Carataşu, 'Un manuscrit inédit du Docteur Jean Comnène', 113.

75 Ibid., passim.

76 Vasiliu, 'Costantino Brâncoveanu', 110-3. 
It was on the decision of Stolnic Cantacuzino and Prince Brânconveanu that Chrysanthos and Rădu were sent to Padua, where their activities included the printing of maps sponsored by the Wallachian Court. The most important of these is an original map of Wallachia, the first of its kind. This map resulted from a revision of degrees of longitude and latitude, and provides an abundance of information of geophysical, archaeological, political and economic character. Preserved in a single copy in the British Museum, the map has been the subject of several studies. A beautiful object, it bears a dedication to the Prince Brâncoveanu and is decorated with his arms and portrait. ${ }^{77}$ The second map is the first 'mappa mundi' in Greek. It also bears the portrait of the Prince of Wallachia and the arms of the principality. Evangelos Livieratos and his team have shown that it is related to Dutch cartography-at that time in its golden age-especially because it indicates the routes followed by the Dutch United East India Company (Vereenigde Oostindische Compagnie) in all oceans, a feature which is to be found on an anonymous map (Amsterdam or Paris ca 1670) - and also on Guillaume Delisle's world map printed in 1700 in Paris, something which is puzzling. ${ }^{78}$ Finally, there is a small 'mappa mundi' included in the Introduction to Geographics and Sphaerics of 1716, which is explicitly dated to 1700, however. It is based on a Dutch map of Jan Luyts (Utrecht 1692), also published with a geographical work of the latter. ${ }^{79}$

Significantly, Chrysanthos and Rădu printed these three maps at the press of the 'Seminario vescovile' of Padua. This was an exception for Orthodox publishing activities, which usually used private printers in Venice in order to circumvent Roman censorship. But this was not the intention in this case. Created in 1684 by Cardinal Gregorio Barbarigo ${ }^{80}$ on the model of the Propaganda fide, the seminary's press was richly endowed and followed a clearly confessional purpose: to publish texts in rare languages for the conversion of infidels and Eastern schismatics. ${ }^{81} \mathrm{In}$ this sense, the choice of this printing house is extraordinary. It is to be explained

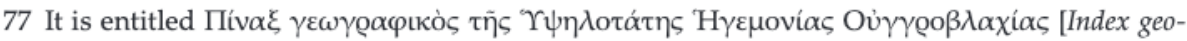
graphicus of the Very-High Principality of Hungary-Wallachia] (Padua 1700). See I. Bianu and D. Simonescu (ed.), Bibliografia Românească veche 1508-1830, IV (Bucharest 1944) 27-8; G. Tolias, 'Maps printed in Greek During the Age of Enlightenment, 1665-1820', e-Perimetron 5/1 (2010) 1-48, here p. 19.

78 E. Livieratos, Chr. Boutoura, M. Pazarli, N. Ploutoglou and A. Tsorlini, 'The very first printed map in Greek, a derived map from Dutch cartography: Chrysanthos Notaras' world map (1700) vs Jan Luyts' world map (1692)', e-Perimetron 6/3 (2011) 200-18.

79 Ibid., passim. It has to be noted that Chrysanthos and Luyts had common beliefs in scientific areas, which they clearly expressed in their geographies: both followed the Ptolemaic astronomical system, and defended geocentrism, despite their firm knowledge of the modern heliocentric theories.

80 It should be noted that Barbarigo professed heliocentrism in secret: see Beretta, 'L'héliocentrisme à Rome', 548 .

81 On this printing press, see G. Bellini, Storia della Tipografia del Seminario di Padova (1684-1938) (Padua 1938); M. Callegari, 'Strategie du produzione libraria a Padova nel Settecento', in G. Petrella (ed.), Navigare nei mari dell'umano sapere. Bibliotheche e circolazione libraria nel Trentino e nell'Italia del XVIII secolo. Atti del convegno di studio (Rovereto, 25-27 ottobre 2007) (Trent 2008) 33-43. 
by the close relationship that our Orthodox team had with Komninos-Papadopoulos, and by the excellent relations between Brâncoveanu and Cardinal Albanirelations which are certainly due to some political calculation. Indeed, as stated by Albani, 'being an absolute and schismatic prince', Brâncoveanu needed to be convinced 'not by force, but only by good manners and an ingenious policy. ${ }^{\prime 22}$ It is thus significant to read in a letter addressed by Chrysanthos to Komninos-Papadopoulos in 1702, that 'for four years', i.e. since 1698, he had tried 'to introduce to these good Lords some favorable opinion of the Latins. ${ }^{83}$

As I hope I have shown through this series of episodes, Chrysanthos was far from being a neophyte when he arrived in Paris in April 1700. Quite the opposite. Although he had not received any comprehensive training in the new sciences, he was experienced in astronomical questioning and practiced cartography according to the methods of his time. In addition, he had strong networks behind him, including a Catholic network open to the new science, and an Anglican network ready to supply instruments through the Levant Company. Through his reading of Verbiest, his conversations with Milescu and the many exchanges that Dositheos and Constantine Cantacuzino had had with Protestants, he knew the current scientific-religious issues, the orientations of 'Jesuit science' and the renewed debates on the astronomical validity of calendars, both Julian or Gregorian.

\section{The exceptional year 1700 and Cassini's scientific-religious project}

Cassini, a committed Catholic

In the framework described above, Giovanni Domenico Cassini's own religious commitment is well-known, though all too often this has been overshadowed by the attention paid to his first-rate discoveries, notably on the rings of Saturn and its satellites ${ }^{84} \mathrm{~A}$ student of the Jesuits and a disciple of Riccioli in Bologna, the eminent astronomer remained in contact with several missionaries who often shared with him their geographical and astronomical observations abroad. ${ }^{85}$ Faithful of

82 Vasiliu, 'Costantino Brâncoveanu', 118: 'essendo Principe Assoluto e scismatico, nulla si potrebbe rimediar con cattivo, ma solamente con le buone maniere, e con ingegnosa Politica.'

$83 \mathrm{Ibid} ., 115$, 118: 'quanto in quattro anni s'è fatto per introdur in quei SS-ri qualche buon concetto de' Latini.' As illustrated by Vasiliu (ibid., 114, note 2), Komninos-Papadopoulos firmly believed that Chrysanthos had embraced in secret the Catholic faith ('ben affetto alla fede cattolica, di cui nascostamente professa I dogma'). Since double-speak is largely used in these exchanges, it is difficult to say if Chrysanthos was sincerely convinced by his master while in Padua, or if he pretended so to maintain good relations with him.

84 As briefly mentioned above (footnote 33), Cassini enjoyed court life. To understand the singularity of this exceptional Italian scientist, let us recall here that he was trained by the Jesuits of Genoa, appointed professor of astronomy at the University of Bologna when he was twenty-five years old, and called to France by Colbert in 1669 after the publication of his Ephemerides Bononienses Mediceorum siderum (Bologna 1668).

85 See for instance a report with observations from Smyrna, Thessaloniki, the Aegean Islands and Crete, sent by Louis Feuillée, a friar of the Order of Minimi and a scientist: 'Extrait des observations astronomiques que le R. P. Feüillée Minime a faites au Levant pendant les années 1700 et 1701', Histoire de l'Académie royale des Sciences, a. 1702 (Paris 1743) 7-15. On this 
the Catholic Church, he never openly defended heliocentrism. Officially, he appeared as a defender of the cosmology of Ptolemy, ${ }^{86}$ confining himself to the practical applications of the new science. For that reason, it has been said of him that 'he passed quietly from one system to another without displaying his opinions. ${ }^{\prime 87}$

An autobiographical note copied by his son Jacques begins with an episode of his childhood where he appears to have been fascinated by St Francis Xavier, the so-called apostle of the Indies: 'Having heard in the church of St Ambrose a panegyric of St Francis Xavier, he immediately translated its most beautiful parts into Latin verses and presented them to his regent. And the latter made him Prince of Poets of his class. ${ }^{\prime 8}$ It was also under such inspiration that he concluded his essay De l'origine et du progrès de l'astronomie:

To what we have said about the utility of Astronomy we can add the advantages that we have gained and that we receive from it every day for the propagation of the Faith. Thanks to the acknowledgment and the protection of this science, those who have devoted themselves to the preaching of the Gospel to unbelievers penetrate into the most remote countries and live not only securely, but also completely free to preach the Faith, enjoying the admiration of the people, gaining access to the privacy of great men, and even winning the favor of the sovereigns. This science opened to missionaries the vast empire of China, whose entrance was closed to all foreigners by the laws of the country and reasons of state ${ }^{89} \mathrm{It}$ has helped to gain permission to build churches and to practice publicly the true religion. This is why the king [Louis XIV] wanted the missionaries who went to preach the Gospel to China, to the kingdom of Siam, and to the other East Indian states, to be instructed in the ways in which the Academy [of Sciences] makes astronomical observations, and to receive its broad instructions of what they should do and what they should note during their journey.

The observations which these missionaries have already made in accordance with the Academy and which they have sent to it, being compared with those which have been made at this same time at the Observatory, have already proved enlightening. We cannot doubt that the [observations] which we shall continue to make in these faraway lands, will contribute much to the progress of Astronomy. If the people who practice this science

subject, M. Cams, 'Les missions jésuites en Extrême-Orient et les échanges de connaissances cartographiques (XVII $-\mathrm{XVIII}{ }^{\mathrm{e}}$ siècles)', in C. Hofmann and Fr. Nawrocki (eds), Le monde en sphères (Paris 2019) 160-5.

86 Cassini's efforts to 'save' Ptolemy appear in an unpublished work, Ptolemaica methodus apogaeorum excentricitatum et anomaliarum ad geometricam normam emendata et promota, followed by Correctiuncula theoriae Ptolemaicae et aliorum omnes concilians. It is preserved in the manuscript Bibliothèque de l'Observatoire de Paris [= BOP], B4/2 (7), https://bibnum.obspm.fr.

87 See A. Danjon, 'Jean-Dominique Cassini et les débuts de l'Astrophysique', L'Astronomie 77 (1963) 4-16, here p. 12: 'il passa discrètement d'un système à l'autre sans afficher ses opinions.'

88 'Note sur J. D. Cassini écrite de la main de Jacques Cassini son fils', BOP, B4/3 (3), f. 33r.

89 Allusion to Verbiest's achievements in China (see above, footnotes 39-40). 
in foreign countries carry on a correspondence with the Academy and convey their observations in the same way that [the Academy] shares these same with them, there is reason to hope that in a short time not only Astronomy, but also Geography and the art of Navigation will be brought to the highest perfection. ${ }^{90}$

While in Italy, Cassini had benefited from the benevolence of Pope Alexander VII, to whom he had presented an engraved map of the universe in 1659: Systema revolutionum superiorum planetarum circa terram ab anno 1659 ad sequentes per tricenos dies. ${ }^{91}$ Using his geographical skills, Clement IX, the successor of Alexander VII, charged him with the task of setting the borders of the Papal States and Tuscany. ${ }^{92}$ Finally, when Cassini had already been settled in France for a long time, Clement XI appointed him as consultant to an ephemeral Congregation of the Calendar, which was formed within the Congregation of Rites. Presided over by Cardinal Enrico Noris, ${ }^{93}$ it also included the astronomer Francesco Bianchini, Cassini's long-time correspondent, ${ }^{94}$ as well as Giacomo Filippo Maraldi, his nephew and close associate. Very little is known about this commitment to the question of the Calendar. However, it is recorded in a report of the Academy of Sciences dated 1701:

The question of the Calendar [...] was treated in Rome in a Congregation established by the Pope [...]. It was to investigate whether there was any reform to be made in the Gregorian calendar, in order to remove any reason for the Protestant states not to accept it. Cardinal Noris received an order from the Pope that the Congregation should correspond with Cassini on this subject, and letters were written to him several times, by M. Bianchini, secretary, and by M. Maraldi, who had gone to Rome after Bianchini finished his work on the meridian-with which M. Cassini had given him much help-having received the honor of being appointed by the pope to participate in the Congregation of the Calendar. The opinion of M. Cassini was that nothing was lacking in the Gregorian calendar, no reform to be made, as long as the intention of Pope Gregory XIII was followed exactly, and there was no deviation from it in any way. ${ }^{95}$

90 Cassini, 'De l'origine et du progrès de l'astronomie', 42-3 (my translation).

$91 \mathrm{~J}$. D. Cassini, Mémoires pour servir à l'histoire des sciences et à celle de l'Observatoire royal de Paris, suivis de la vie de J.-D. Cassini écrite par lui-même (Paris 1810) 326-7.

92 Ibid., 329.

93 Ten years earlier, Enrico Noris had published his Dissertationes duae. I. De Paschali Latinorum cyclo annorum LXXXIV. II. De cyclo Paschali ravennate annorum XCV (Florence 1691).

94 Beretta, 'L'héliocentrisme à Rome', 537-41. Three letters of Bianchini to Cassini have been preserved: BOP , B 4/9 (54bis), 29 June 1699; B 4/9 (55), 25 April 1702; B 4/9 (56), 7 April 1705.

95 [Anonymous], 'Sur le calendrier', Histoire de l'Académie royale des Sciences, a. 1701 (Paris 1704) 107 (my translation). 
Many writings such as unpublished observations and published reports ${ }^{96}$ revealed the views of the astronomer in this matter. Among other things, Cassini was interested in the adjustments of the epact and the reintroduction of the Golden Number, the establishment of updated astronomical tables and the identification of the so-called Paschal Moons. Discussions on this subject continued until 1704, when Cassini presented to the Academy of Sciences some Réflexions sur des Mémoires touchant la correction grégorienne communiquées par M. Bianchini ${ }^{97}$. I shall not dwell on this little-explored question, which deserves extensive research. Here, however, are some chronological milestones which I was able to identify in the extensive documentation left by Cassini and his collaborators:

- 1680-1683. Two reports titled Sur les périodes lunisolaires ou sur le règlement des temps, ${ }^{98}$ and 'Diverses additions et corrections au calendrier'. ${ }^{99}$

- 1690, 22 August. Incognito visit of king James II of England to the Observatory. Among the many exchanges that took place during this visit, this one is of interest for the calendar question:

His Majesty has shown two silver plaques shaped as a medal, one of which was used to find for every day the corresponding day of the week, during several centuries, the one according to the Julian calendar, the other according to the Gregorian calendar. But [H. M.] said that the latter was erroneous, and could only serve until the end of the present century, because it had not been taken into account that it was necessary to remove the year 1700 . This gave an opportunity to Mr Cassini to speak of an exact and perpetual Table he had made for the Gregorian calendar. ${ }^{100}$

96 See, for instance, the following archive documents of the Bibliothèque de l'Observatoire de Paris: 'Canonum Calendarii Gregoriani supplementum', B 4/1 (13); 'De usu tabularum', B 4/1 (23); 'Quelle est la lune qu'on doit appeler la lune de mars', B 4/1 (51); 'Ensemble de textes latins relatifs aux calendriers grégoriens et juliens', B 4/1 (52)-(53); 'Quelle est la lune de mars', B 4/1 (68); 'Sur cette question. Quelle doit être la lune de mars', B 4/1 (78); 'Sur le calendrier' (1701-1703), B 4/3 (68); 'Continuation du calendrier', B 4/3 (69); 'Réflexions sur l'ancien canon pascal de Saint Hippolyte', B 4/3 (77); 'Sur la proposition d'accorder les calendriers', B 4/3 (79); 'De la justesse admirable de la correction grégorienne des cycles lunaires', B 4/3 (80); 'De la règle des temps', B 4/4 (3). Often anonymous, these documents are related to Cassini and his collaborators. Several have been included in reports of the Académie royale des Sciences under the name of J. D. Cassini or under his authority: 'Sur le calendrier', Histoire de l'Académie Royale des Sciences, a. 1700 (Paris 1741) 127; 'Sur le calendrier', ibid., a. 1701 (Paris 1704) 107-10; 'De la correction grégorienne des mois lunaires ecclésiastiques', ibid., a. 1701 (Paris 1719) 367-84; 'Sur le calendrier', ibid., a. 1703 (Paris 1720) 91.

97 [Anonymous], 'Réflexions sur des Mémoires touchant la correction grégorienne communiquées par M. Bianchini à M. Cassini', Histoire de l'Académie royale des Sciences, a. 1704 (Paris 1704) 142-5.

98 [Anonymous], 'Sur les périodes lunisolaires ou sur le règlement des temps', in Histoire de l'Académie royale des Sciences, I. 1666-1686 (Paris 1733) 314-7.

99 See [Anonymous], 'Diverses Observations Astronomiques', in Histoire de l'Académie royale des Sciences, I. 1666-1686 (Paris 1733) 383.

100 [Anonymous], 'Astronomie', in Histoire de l'Académie royale des Sciences, II. 1686-1699 (Paris 1733) 94-104, here p. 103 (my translation). 
- 1697. Together with Bernard de Fontenelle, ${ }^{101}$ considerations on the Paschal Canon of Saint Hippolytus of Rome and refutation of the proposals of the Protestant scientist Erhard Weigel on the universal calendar:

Mr Erhard Wegelius, professor of Mathematics at Jena, asked for the judgment of the Academy on a means he proposed for adjusting the calendar of all Christian peoples; $\mathrm{Mr}$ Cassini was charged to examine this; the Author desired that in each kingdom a Company should be established which would pay particular attention to the correction of the calendar, [...] but only on the basis of astronomical observations, as was done in the first five centuries of the Church. M. Cassini replied that with regard to the Companies for the correction of the Calendar, it was up to those who followed the Julian calendar to provide for this, since those who followed the Gregorian found [this calendar] perfectly in agreement with Heaven, and had no new measures to take in this respect; that the Gregorian calendar did not exclude astronomical observations, and that it was adjusted to the entire extension of the solar year..$^{102}$

- 1700. Observations on the Lunar eclipse of 5 March 1700 (Paschal Moon):

As on the Gregorian Calendar there are always three century years in a row out of four which are not century leap-years, although by nature they should be so and the year 1700 was one of them, M. Cassini, who had found an easier rule than that of this Calendar to determine the epacts of those years, wished to see if the epact which had provided him with the rule coincided with the day of the eclipse which had just been observed. According to this epact, the full moon fell exactly on 5 March. ${ }^{103}$

- 1701. Memorandum on changes that occurred in Europe following the adjustment of the calendars. ${ }^{104}$

101 [B. Le Bouyer de Fontenelle], 'Sur l'Ancien Canon pascal de StHippolyte', Histoire de l'Académie royale des Sciences, II. 1686-1699 (Paris 1733) 300-17; the same year, [B. Le Bouyer de Fontenelle], 'Sur les deux éclipses de cette année, et principalement sur celle de Lune, employée à l'examen du calendrier', Histoire de l'Académie royale des Sciences, II. 1686-1699 (Paris 1733) 322-31.

102 [Anonymous], 'Sur le calendrier et sur la différence entre les cycles lunaires et solaires', Histoire de l'Académie royale des Sciences, II. 1686-1699 (Paris 1733) 318-22, here p. 318 (my translation). On Weigel's theories on the calendar, see E. Koller, Strittige Zeiten. Kalenderreformen im Alten Reich, 1582-1700 (Berlin-Boston 2014) 338-99; J. Hamel, 'Erhard Weigel und die Kalenderreform des Jahres 1700', in R. E. Schielicke, Kl.-D. Herbst and St. Kratochwil (eds), Erhard Weigel-1625 bis 1999. Barocker Erzvater der deutschen Frühaufklärung (Frankfurt a.M. 1999) $135-56$.

103 [Anonymous], 'Sur l'éclipse de Lune du 5. Mars', Histoire de l'Académie Royale des Sciences, a. 1700 (Paris 1719) 109-11, here p. 110-11 (my translation).

104 [Anonymous], 'Sur le calendrier', Histoire de l'Académie Royale des Sciences, a. 1701 (Paris 1719) 127-9. 
A European affair: the curious year 1700

As I pointed out at the beginning of this paper, Chrysanthos left Padua for Paris 'on Great Monday, the 5th of April [1700], according to the Italian calendar', and it seems to me that this date was not incidental. At this time, a month had passed since the eclipse of the Paschal Moon observed by Cassini, and thirty-two days since a notable event in European history: the removal of the leap-day in February in Catholic countries which had already adopted the Gregorian reform, and the adjustment of eleven days for several Protestant countries which still kept the Julian calendar. ${ }^{105}$ In France, Belgium and most Catholic countries, the suppression of 29 February was no big problem. There was fear, however, of a non-coincidence between the real full moon and the Paschal Moon-a fictitious representation of the eclipse of the full moon which occurs after the vernal equinox and which is used to determine the date of Easter. For this would have made it necessary to correct the computation of Pope Gregory XIII. The difficulty was all the greater because this computation was based on the geocentric hypothesis which the astronomers of the Observatory had tacitly dismissed. In the Protestant regions of Germany, the Netherlands, Denmark, and Sweden, the question was even more delicate. The aim was to reform the Julian computation, the errors of which had become too obvious, without proving the correctness of the Catholic astronomical Tables. On 28/18 February 1700, Europe held its breath; and on 5 March, the time arrived to verify if the Paschal Moon was also a full moon 'according to the astronomical truth'.

In the event, Cassini did not see much that night, because 'the sky was covered in Paris. ${ }^{106}$ However, in a report kept at the Observatory, he noted:

On the occasion of this eclipse, which occurred in the first century year without a leap-day in the form of the Gregorian calendar, I examined my method of finding the days of the new and full moons in perpetuity by my great period of 11600 Gregorian years which begins the common year of JC. [...] The epacts that are found by this very simple rule agree with all century years which are calculated in the Table [of the moveable feasts of the Gregorian computation], although they sometimes exceed by one day that of common century years, as it happens this present year, and the following century year, namely 1800 . But the restoration of these epacts to century leap-years in the period of 11600 years, confirms the accuracy of the Gregorian periods and make them consistent with the astronomical periods. ${ }^{107}$

105 See Koller, Strittige Zeiten, 409ff.

106 'Éclipse de lune du 5 mars [1700]', BOP, B 4/3 (25), 183r (my translation): 'Le ciel étoit couvert à Paris le matin du 5 mars de cette année 1700 à l'heure où nous devions voir le commencement de l'éclipse.'

107 Ibid., 183r-v (my translation): "À l'occasion de cette éclipse arrivée la première année centième non bissextile dans la forme du calendrier grégorien, j'ay examiné ma méthode de trouver les jours des nouvelles et pleines lunes à perpétuité par ma grande période de 11600 années grégoriennes qui commence l'année vulgaire de JC. [...] Les épactes qui se trouvent 
The adjustment advocated by Cassini to make the real full moon coincide with the fictitious Paschal Moon, had thus made it possible to save the Gregorian computation and his geocentric hypothesis at little cost. It had also shown that the Observatory, founded by the Most Christian King Louis XIV, was not only at the forefront of science, but acted as a universal authority helping to resolve ecclesiastical questions which had long divided Europe-in the same way that Alexandrian science had sustained the decisions of the Council of Nicaea in 325. This idea is clearly expressed in the Memorandum of 1701, which summarizes the exchanges between the Academy of Sciences and the German philosopher and scientist Gottfried Wilhelm Leibniz: $:^{108}$

A movement which took place this year in Germany, and which had some connection with the Academy of Sciences, has made clear how important Astronomy is on certain occasions for ecclesiastical and political affairs. The reform of the Gregorian calendar, although necessary and well concerted, was not accepted by the Protestants because it came from Rome. [...] In making this astronomical calculation Mr Leibniz was instructed to consult the Academy. He did so in a letter sent from Hannover and dated 8 February 1700. After exposing the fact [...], he added that 'as once the Church had appealed to the mathematicians of Alexandria in order to execute the canons of the great Council of Nicaea, and to be informed of the true time of Easter, it was convenient on the present occasion to follow the advice of excellent astronomers'; and that 'since the king, by a magnificent foundation, of which there were no other examples in Christendom, had just established forever the Academy of Sciences, it was a relief which his Majesty gave to the Church in these matters, and of which it was necessary to take benefit.' ${ }^{109}$

In this case, Rome was behind. The Congregation of Rites dithered: in 1701, it had not yet decided anything, and it was also at that moment that the Calendar Congregation was created, of which I have spoken earlier. By contrast, Gallican France had clearly and immediately imposed its own perspective:

In Rome ways were sought for a complete conciliation on the Calendar, and the Congregation of Rites was working on it. The King ordered that the Academy should remain far from what was being done in Rome; but if it

par cette règle si simple s'accordent à toutes celles des centièmes bissextiles qui sont calculées dans la dite Table, bien qu'elles excèdent quelquefois d'un jour celle des centièmes communes, comme il arrive cette même année, et la suivante centième 1800. Mais le rétablissement de ces épactes aux centièmes bissextiles dans la période de 11600, confirme la justesse des périodes grégoriennes qui les rétablissent conformes aux astronomiques."

108 For Leibniz's positions on the calendar question, see G. W. Leibniz, Sämtliche Schriften und Briefe. Dritte Reihe: Mathematischer, naturwissenschaftlicher und technischer Briefwechsel, VIII (Berlin-Boston 2015) xxvii-xxxiii. It must be specified that Leibniz had had exchanges with Cardinal Noris since 1689. See, ibid., xxx.

109 [Anonymous], 'Sur le calendrier', Histoire de l'Académie Royale des Sciences, a. 1701 (Paris 1719) $127-9$. 
could satisfy what was requested [from Rome], he left it free. [...] The king had written to the prince of Monaco, then his ambassador in Rome, to tell him what had happened in France regarding the calendar, and the prince of Monaco had replied to the count of Pontchartrain in a letter of 3 August 1700 that he had spoken of this affair with cardinal Spada, who had greatly praised the king's attention to the court of Rome, and had told him that the Congregation of Rites would not take any decision without consulting the Academy of Sciences, which is much more enlightened on these subjects than anyone in Italy. ${ }^{110}$

Such was the political and religious context in which the nephew of the patriarch Dositheos and the son of Stolnic Constantin Cantacuzino left Padua for Paris and the Observatory. In my opinion, it would be particularly naive to consider that this journey, on which Chrysanthos met not only Cassini, but also Gallican theologians, was a simple study trip. The whole of Europe was talking about the reform of the calendar. If the Observatory-the new Alexandria, according to Leibnizwelcomed with honors an archimandrite keen on science, accustomed to dialogue with the Catholics and who enjoyed the full confidence of Christian elites of the Greek East, it is certain that the calendar question was also on the agenda: astronomy and religious affairs still remained intimately connected.

\section{Chrysanthos invited to the Observatory: new considerations}

We do not have explicit sources to affirm that Chrysanthos' visit to Paris was related to the calendar reform. However, what has been stated above constitutes strong circumstantial evidence, which is further reinforced by the curious visit of Rădu Cantacuzino to Cardinal Albani-a visit which took place shortly before the Paris trip. ${ }^{111}$ Indeed, the future Clement XI was involved in the calendar debate; he was very close to the astronomer Francesco Bianchini, who at the end of 1700 became Papal Chamberlain ('cameriere d'onore'). The present state of research does not allow us to say much more about this visit for the moment; but it should be noted that in a letter of appreciation and congratulation sent the next year to Clement XI, Brâncovean signals his attachment to the new Pope with a quite rare expression for an Orthodox: 'summum Romanum adoro et veneror Pontificem.' The Pope's answer is also explicit: the lamb must hasten to join his pastor for the unity of the flock and for his own salvation. ${ }^{112}$

In fact, since the sixteenth century, the Gregorian reform had exacerbated the schism. Solicited by Gregory XIII and initially willing to discuss this subject, Ieremias II of Constantinople had soon adopted a hostile attitude to the calendar

110 Ibid., 129.

111 Vasiliu, 'Costantino Brâncoveanu', 112-3. Rădu's visit to Albani occurred in the beginning of 1700 .

112 Ibid.: 'si pastoris, quem gerimus, vocem oves salutaria pascua ultro accurrentes agnoscant et ad dominicum gregem in eisdem unitate iugitur permansurae festinent.' 
reform, fearing a changeover to Rome in the Romanian Principalities and the Ukraine. ${ }^{113}$ From then on, the Orthodox Church repeatedly expressed its strong attachment to the doctrine of the Council of Nicaea. In the seventeenth century, Dositheos himself had briefly but explicitly condemned the Gregorian reform in a chapter of his History concerning the Patriarchs in Jerusalem ${ }^{114}$ Furthermore, in an unpublished part of the same work conserved in the manuscript MPT 242 [Diktyon 6639], the Patriarch developed his point of view on the question, strongly rejecting the authority of astronomy over Tradition:

It was not sufficient for the Pope of Rome to assert [...] nonexistent stories, but now he poses astronomy in principle of the Holy Passover, [astronomy] which all the Holy Scripture and all Holy Fathers reject and expel from the Holy Church as vain and false. But if the Greeks themselves insulted it [...], should not the Christians consider it detestable, and the teacher of pagan and impious doctrines? Now, concerning the feast of the Holy Passover, we are talking about years, equinoxes, full moons, but we do not take astronomers as principles. ${ }^{115}$

Educated by his uncle on ecclesiastical matters, Chrysanthos could neither ignore nor openly oppose this latter's positions. Because of his more affable personality and his keen interest in astronomy, he could, however, give hope to some Catholics, including his teacher Nikolaos Komninos-Papadopoulos, that he would adopt a more moderate point of view. Through Cassini, all these people hoped to make him accept, at least, the 'astronomical truth', which had already received the support of Leibniz and German Protestants. As to the position of the Wallachian court, it seemed more flexible, as appears from the correspondence of Brâncoveanu I have just quoted. Finally, the French context in which the discussion was to be held had two advantages over Rome: more neutral because of Gallicanism, France was also politically more acceptable to the Ottoman power. Thus, we can assume that Catholic scholars had put all their hopes in this visit. A switch of the Orthodox to the Gregorian computation, or at least to the 'astronomical truth', would not

113 See Chr. Hannick and K.-P. Todt, 'Jérémie II Tranos', in C. G. Conticello and V. Conticello (eds), La théologie byzantine et sa tradition, II. XIII $-X^{e} I X^{e} s$. (Turnhout 2002) 551-615, here p. 563-6; V. Tzoga, 'Sigillion inédit du patriarche de Constantinople Jérémie II et d'Alexandrie Sylvestre sur la réforme du calendrier', Byzantinische Zeitschrift 107 (2014) 221-52.

114 Dositheos, History, 1169 (Book XI, ch. 8), 1192 (Book XII, ch. 2, § 2).

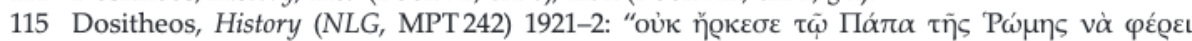

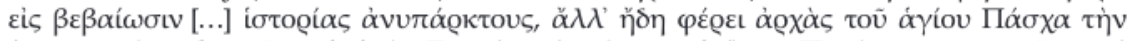

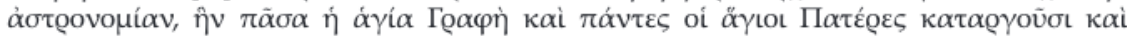

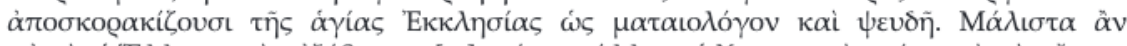

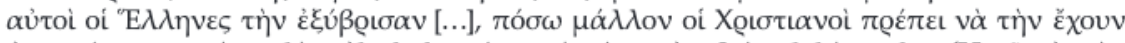

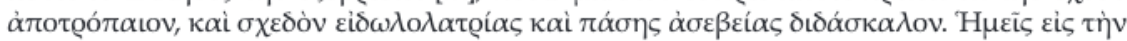

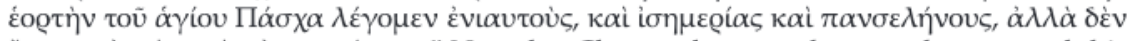

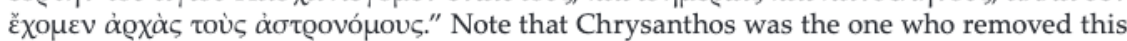
passage from the posthumous edition of the History. I am grateful to Kostas Sarris for having indicated me this unpublished passage. 
only have been a step towards union; it would also have given the endorsement of the hierarchies of Nicaea and Alexandria-historically important for the determination of the date of Easter-and reconciled the principles of ancient with the discoveries of modern astronomy.

Cassini himself could not neglect this aspect, as he drew much of his information from missionaries and explorers. To have on the spot, in the East, in Constantinople, Nicaea or Jerusalem, a collaborator experienced in the new science, able to make accurate astronomical observations and to transmit his data to the Observatory, would have been an asset for him personally. Chrysanthos was a good candidate. Although he was busy preparing his 'Voyage de la Méridienne', Cassini took the time to explain to the archimandrite the equivalence of the measurements and to show him how to use the new instruments. He also guided him in the construction of instruments, and perhaps provided him with several of them. In short, one may assume that he prepared him and equipped him, hoping that he could be one of his informers in the East.

Did he also try to convince him of the relevance of Gregorian computation, or at least of the necessity of referring to the new Tables of the Observatory? As already stated above, this hypothesis seems highly probable in the context of the spring of 1700 . Chrysanthos was of a scientific mind. During his week at the Observatory, while scanning the movements of the Moon and planets through the large telescopes, he was perhaps seduced by the 'astronomical truth'. However, he remained absolutely faithful to the orientations given by his uncle Dositheos, and did not reveal anything. The richly illustrated publication of his Introduction to Geographics and Sphaerics was the only fruit-delicious to him-of his stay in Paris. And two years later, when he became metropolitan of Caesarea in Palestine, and thereby the appointed successor to the patriarch of Jerusalem, Mavrokordatos congratulated him on his choice. As the Great Interpreter of the Porte had understood, 'nothing was more admirable than his return. ${ }^{.16}$

\section{Conclusions}

From a very early stage, the visit of Chrysanthos Notaras to Paris, and his scientific meeting with Giovanni Domenico Cassini, was considered as the tipping point in which the new science, and thus modernity, entered Eastern Christianity. The archimandrite has for this reason been depicted as a forerunner of the 'Modern Greek Enlightenment.'17

However, this visit is problematic. While it undoubtedly took place, there are still many grey areas, and the legend built around Chrysanthos has further obscured them. In 1700, when he arrived in Paris, the archimandrite was about forty years old. He was not a neophyte in the scientific field: he knew well the cosmol-

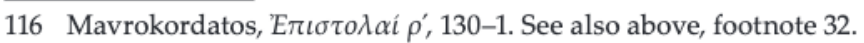

117 Stathi's monography is even titled (in translation): Chrysanthos Notaras ... Forerunner of the Modern Greek Enlightenment (see above, footnote 2). 
ogy of Ptolemy, he had studied books of Arab-Byzantine astronomy, he had mastered the use of the astrolabe. If we go a little further in the analysis of sources, we also see that his many visits to the Wallachian court, between 1684 and 1696, had put him in contact with new science; that his trip to Moscow in 1692 gave him access to the Compendium of Ferdinand Verbiest; finally, that a purchase order placed in England by his uncle Dositheos in 1689 contains several geographical tools of which he seems to be not only the recipient, but also the sponsor.

This order is interesting in many respects. It shows among other things the exchanges that Dositheos' network had with important agents of the Levant Company, and the desire of some Anglicans, like John Covel, to make the patriarchate of Jerusalem adhere to their own religious choices. But the Protestants were not the only ones to materially support the action of Dositheos from the point of view of proselytism. The Catholics-who had briefly approached the Patriarch in the 1670s-had a similar attitude towards the Wallachian court and thereby towards Chrysanthos. Thus, the 'Seminario vescovile' of Padua welcomed in its printing works a cartographic operation sponsored by Brâcoveanu and Stolnic Cantacuzino and implemented by our archimandrite and Rădu Cantacuzino. In the same period, the latter was received in Rome by Cardinal Giovanni Francesco Albani, a powerful Church dignitary interested in the new science, who was to become Pope a few months later. Moreover, the two men spent three years with Nikolaos Komninos-Papadopoulos, a Catholic Greek well integrated in Roman ecclesiastical circles.

Considering Chrysanthos' host in Paris, namely Cassini, another complicating factor must be added to this evidence: the proximity of the famous astronomer to this same Catholic background-a proximity which is often overlooked. Raised at the Jesuit school, the scientist had been the disciple of Giovanni Battista Riccioli, and had maintained constant links with the missions; he had been the advisor of two Popes; one of his scientific correspondents was Francesco Bianchini, the right-hand man of cardinal Albani; his nephew Giacomo Filippo Maraldi, who participated in the 'Voyage de la Méridienne', became a member of the Calendar Congregation in 1701; finally, he himself was consulted over a long period, from 1680 to 1701 , about possible corrections to the Gregorian calendar.

In fact, the year 1700 was about to introduce a shift in this calendar and thus render obsolete the decisions of the Pope Gregory XIII who had instituted it in 1582. King James II of England had ironically reminded Cassini of this problem when he visited the Observatory in 1690 . Having never officially supported heliocentrism, the astronomer had all the confidence of Catholic circles, especially on this issue. He had therefore been called to the rescue, and had responded to this mission with the utmost dedication. Thanks to his calculations, but also to his authoritative announcements, the Gregorian calendar was saved. Better, many Protestant countries-although not England-agreed to conform to the 'astronomical truth' which was also his.

For the unification of Christendom under one calendar-a necessarily Roman calendar-it was important to convince the Orthodox, who were strongly attached 
to the Julian calendar and had remained hostile to any such reform since the sixteenth century. Ferdinand Verbiest, a Jesuit missionary who had achieved the feat of introducing the Gregorian calendar in China, had made an attempt to persuade the Tsar Alexis I, but this had failed completely. Brâncoveanu's desire to print the first modern map of Wallachia, and the study trip of Chrysanthos and Rădu to Padua, appeared as an opportunity to be seized. In any case, in 1700, when the question of the accuracy of the Gregorian calendar was in full swing in Europe, the two men were invited to Paris and welcomed at the Observatory. My position is that the primary purpose of this invitation was to conduct discussions on the calendar, or at least convince the archimandrite of the 'astronomical truth' of Cassini's calculations.

In the present state of research, we do not know if Chrysanthos was tempted during the week spent with his host, or if the discussion broke off immediately. If we consider what he says about it in 1716, the memory he kept of Cassini remained diffuse: in spite of the accent which was put on the event later, Chrysanthos alluded to his stay at the Observatory only in passing, in the form of an interpolation, as if it had been a mere parenthesis in his life. Of his travels in Europe, and especially in Paris, he spoke clearly in his Prologue to the History concerning the Patriarchs in Jerusalem. But here too, we find only sustained praise of Gallican France, and not a word about Cassini, who himself was obviously not a Gallican. Did the close relationship of the astronomer to 'Jesuit science' end up hurting the feelings of the archimandrite? In the same Prologue, Chrysanthos' judgment is explicit: Jesuits are 'these very wise men, at the thought of whom tears come to me, because they get lost in vain doctrines, [...] thus leading [...] the simplest among Eastern and Western Christians to behave towards each other as enemies. ${ }^{.18}$ Should it not be regarded as the sign of a great personal disappointment?

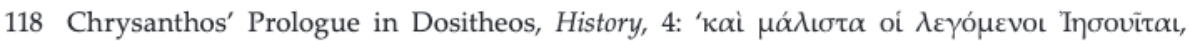

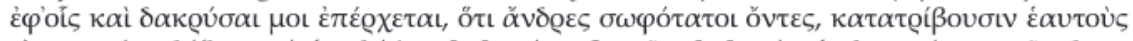

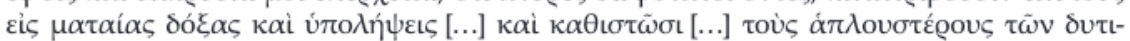

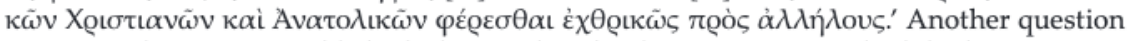
remains: who in Paris, published Chrysanthos' book in 1716? Cassini had died in 1712. 


\section{Appendix}

Dositheos' order in John Covel's correspondence:

Ms. British Library, Harley 6943 (1672-1711), f. 88r-92v

\section{Thomas Coke to John Covel}

f. $88 \mathrm{r}$

Pera October the $9^{\text {th }} 1684$ |

Reverend Sirl

Last March by Mr Baxter a Gentleman of my Lord I sent youl a booke, and papers what it was I know not given me by Ginacchi forl which I hope long are this you have received. Here enclosed I have forwarded to you an other letter of Gionacchi ${ }^{119}$, and a Booke of Nectarius| late Patriarch of Jerusalem against the Supremacy of the Pope, printed at Yasl in Moldavia by the present Patriarch ${ }^{120}$. I have recomended it to the \{c\}are of Mr Barclay a Servant of my Lord's going for England to leave itl at the seaven Stars in Paul's Church yard. The French Ambassador isl \{g\}onne to Adrianople to audience, my Lord was also called to audience butl sicknesse excused him from the journey, tho I doubt whether at the Courtl stay at Adrianople next sumer wee may not ${ }^{121}$ forced to goe. All things arel kept so secret by the Turkes at Court, that wee can heare no newes froml Hungary or Poland, being absolutly ignorant whether Buda be takenl and what State it's in. The Visir ${ }^{122}$ is politicly sick, under color of an ulcerl which he hath in his leg not appearing publicly but very rarely, and that but shortl in dispatch at Divan. The Gran Signore ${ }^{123}$ goes as usually a hunting. Greatl \{p\}reparations are made for next, as is every third man in the Empire, I but tho they may have an numerous army, yet they will be raw, and unexpertl men, and should the Army be beaten it would give a great shake to theirl Empire. If the peace be well settled in Christendome but for a few yeares| \{and\} the confederates ${ }^{124}$ continue united the Turk must make either make al \{v\}ery advantagous $<$ war> peace, or hazard all by persisting in warre. Mr Mauricel \{G\}reene dyed August the 16 at Adrianople of a feavor, and Signore Antonio ${ }^{125}$ is nowl here very sick, it hash been very sickly time there. Sir I must beg your pardonl for my abrupt writting. There being a Ship just now on departure, and one \{that\} departed two days past which hath not permitted leasure to

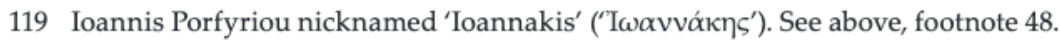

120 Nektarios, On the Primacy of the Pope. See above, footnote 49.

121 Read: not [be]

122 Bayburtlu Kara Ibrahim Pasha, Grand Vizier from 25 December 1683 to 18 November 1685.

123 Mehmed IV, nicknamed 'Avc1' ('the Hunter'), because of his passion for hunting. He reigned from 2 January 1642 to 6 January 1693.

124 The Holy League of 1684.

125 Probably Antonio Perone or Perrone, second interpreter of the British Resident in the time of John Finch, namely from 1674-1681. 
writte tol \{man\}y of my fremds, besides my wife is newly deliverd of a boy that forl $\{\mathrm{I}\}\{\mathrm{h}\}$ ave now three Sonne, these accidents hinder enlarging so withl \{a\}ll respect and affection I remainel

Your reall fremd and humble Servant|

Thomas Cokel

f. $88 \mathrm{v}$

〈Th. Coke. Oct. 9.I 1684 ${ }^{126}$ )For the Reverend Dr John Covill।

To be left at Mr Cooke's a Wollenl draper's at the Seaven Starres inl St Paul's Church Yard with a Greeke bookel a small foliol

Londonl

\section{Thomas Coke to John Covel}

f. 89r To Dr John Covill. Constantinople November the $2^{\mathrm{d}} 1689$.

\section{Copie. I}

Sir I beg your pardon for so long a silence, but I had no newesI concerning you, how, or where to write you till Mr Gerard inlformed me of the favour he seeked from you, and your kind remembranlce of me. I do heastily congratulate your good fortune, and hopel to heare of the augmentation of it. I was latly with the Patriarchl of Jerusalem who sends you the enclos'd letter, and I have froml him two bookes (I suppose) Nectarius against the Popes Supremacy, ${ }^{127}$ and Simeon Metropolite of Thessalonica of the Articles and Rites of thel Greeke Church. ${ }^{128}$ I formerly sent you myselfe these two but knowl not whether they arriv[e]d you, with the first occasion I shall forwardl these to you.

The Patriarch hath desir'd me to procure himl some Greeke bookes of which you have herewith a List, he would have them in Greeke alone, what can be had so, else in Greeke, or Latin, and amongl them all the Byzantine Historians, I know not how many volumes theyl are I think 22. I would not give you this trouble, but yet I know you can't want fremds that at your place can easily procure them, or atl London, and for the Expence Mr Thomas Palmer will furnish youl the mony. He desires also a paire of Globes of about 14 inchesI diameter, and a paire of small globes about the bignesse of one's fistl for to carry easily in a journey, and 4 Maps of the foure parts of thel world, but these all in Latin, and not in English. They desire thel Globes may have two Poles, and the brasse circle to remove from one to the other. He desires also, all the Greeke ComentatorsI on Aristotles Metaphysics,

126 Handwritten note by John Covel.

127 Nektarios, On the Primacy of the Pope. See above, footnote 49.

128 Symeon, Against Heresies. See above, footnote 51. 
as Alexander, Themistius, Ammonius, and Thel bookes must bee carefully packt up, that they bee not damaged, and especially the Globes, that they bee not broken. I beleive the Byzantinel Historians are 24 vol[umes] ${ }^{129}$ and of great price, but what ever the expence is $\mid \mathrm{Mr}$ Palmer will pay it. I desire the price of every booke distinctl as of the other things for my better making up of my account with thel Patriarch.

January the $14^{\text {th }} 1689 / 90$

Reverend Sir the foregoing I sent by way of Venice, but in these dangerous $^{130}$ | for feare of an unlucky accident I send you its duplicate. There has ${ }^{131} \mid$ no opportunity yet presented to forward you the two bookes above mentiond nor will bee till the Convoy comes of which wee are here inl ignorance when it may bee. I am glad to heare of the Kind receptionl you had from his Majestie, and wish you prosperous effects from it.I What newer occurres here I send you in an annext paper, we have no newes of Mr Gerard being departed England. I am your most reall fremd and Server.I Thomas Coke.I

〈Pray send the best Geographical Dictionary I think Ferarius ${ }^{132}$ is so esteemed. $\rangle$

f. $89 \mathrm{v}$

〈T. Coke a Copy. nov. 2.1689| and new letter Jan. 14. 1689/90।〉

For Dr John Covell

$\langle$ Nov. 2d. 1689. Copyl〉

\section{Thomas Palmer to John Covel}

f. $90 \mathrm{r}$

London March 7th 1689/90

Reverend Sir

I have reed yours of first instantl giving Me to Understand that Mr Thomas Coke of Constantinople hadl Intreated you to buy him severale Bookes for the Patriarchl of Jerusalem, and farther acquainting that I will furnish you withl what Mony they shall amount to, such I Promise to Complyl \& pay Unto you when ever Comanding to me. You will havel a long time to provide them not apprehending any Convoy ${ }^{133} \mid$ will goe hence for Constantinople in 12 Months. when Ever any goes ${ }^{134}$ will not faile to give you timely

129 In 1689, thirty-three volumes were already published in this collection, and not twenty-two or twenty-four, as Coke writes in this letter (volume XXIV was edited already in 1660). See above, footnote 52 .

130 Read: dangerous [times]

131 Read: has [been]

132 Filippo Ferrari, Lexicon Geographicum (London 1657; Paris 1670). See above, footnote 57.

133 Read: Convoy [that].

134 Read: goes [I]. 
Notice, in the Interim I you may be providing, have this day advised $\mathrm{Mr}$ Coke of it, Soel with due respects ${ }^{135}$ Crave leave \& remainl

Sir your affectionate humble Servantl

Thomas Palmer

f. $91 \mathrm{v}$

To the Reverend Doctor John Covell

At Christ Collegel

Cambridgel

〈T. palmer. March. 7. 89/90.I

He will pay mel

For the Patriarchs books. $\left.\left.\right|^{136}\right\rangle$

\section{Dositheos' booklist}

f. $92 \mathrm{r}$

† O

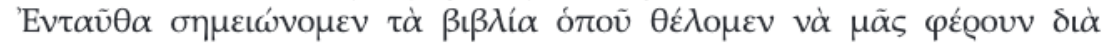

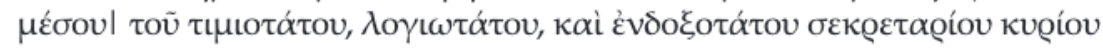

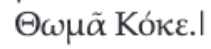

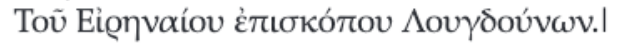

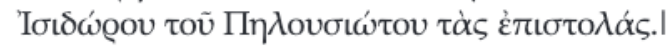

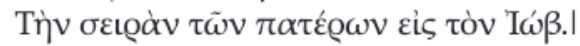

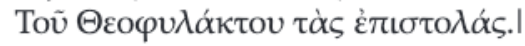

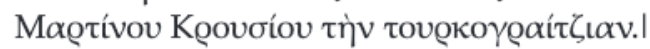

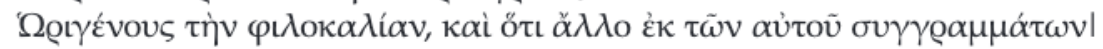

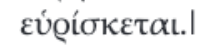

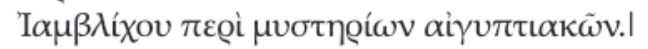

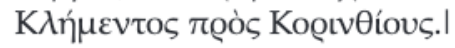

$\Sigma \tau \rho \alpha ́ \beta \omega \nu о \varsigma ~ \gamma \varepsilon \omega \gamma \varrho \alpha \varphi$ í $\alpha . \mid$

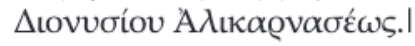

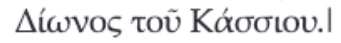

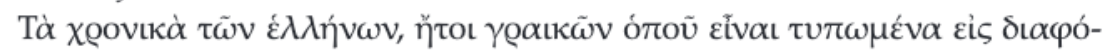
อous тótous.l

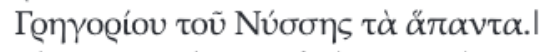

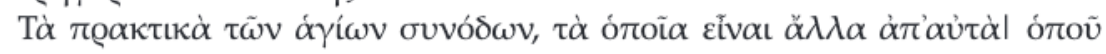

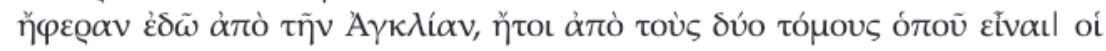

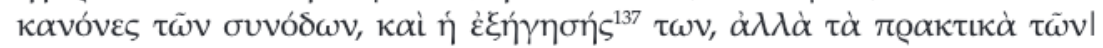

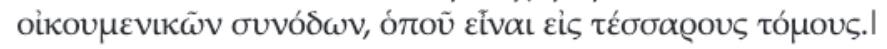

135 Read: respect [I].

136 Handwritten note by John Covel.

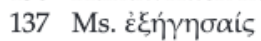




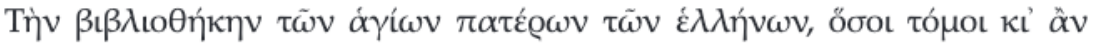

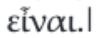

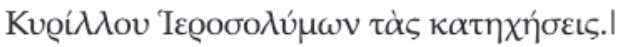

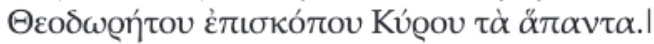

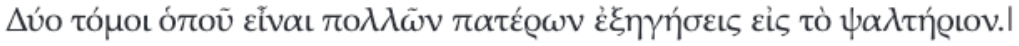

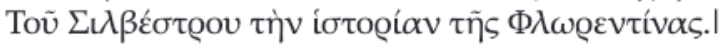

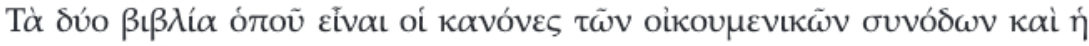
$\dot{\varepsilon} \xi \eta ́ l \gamma \eta \sigma \eta ́ \varsigma^{138} \tau \omega v$.

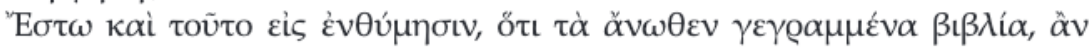

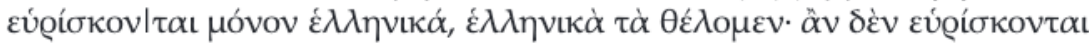

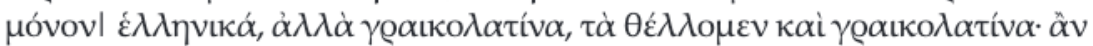

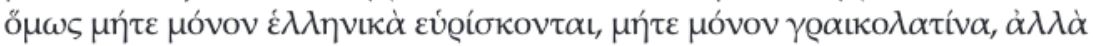

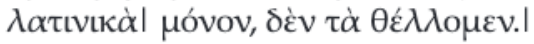

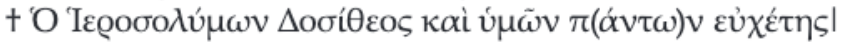

f. $92 \mathrm{v}$

〈List of Bookes to be bought|

B.)

\section{Bibliography}

\section{Archives/Manuscripts}

Athens, National Library of Greece [ $=$ NLG], fonds of Metochion Panagiou Tafou [Metochion of the Holy Sepulchre] [= MPT 242 [Diktyon 6639 (Réseau numérique pour les manuscrits grecs)].139

MPT 93 [Diktyon 6490], MPT 121 [Diktyon 6518], MPT 198 [Diktyon 6595], MPT 200 [Diktyon 6597], MPT 241 [Diktyon 6638], MPT 242 [Diktyon 6639], MPT 261 [Diktyon 6658], MPT 420 [Diktyon 6817], MPT 423 [Diktyon 6820], MPT 429 [Diktyon 6826]

London, British Library, Add 22909 [Diktyon 39022].

London, British Library, Harley 6943 (1672-1711) [Diktyon 39727].

Moscow, Russian State Archive of Early Acts (=RGADA), 52-1, 1701, no. 2.

Paris, Bibliothèque nationale de France [= BnF], Paris, Suppl. gr. 1093 53757].

Paris, Bibliothèque de l'Observatoire de Paris [= BOP (https://bibnum.obspm.fr)], B4/1-4.

Paris, Bibliothèque de l'Observatoire de Paris [= BOP], B 4/9.

Paris, Bibliothèque de l'Observatoire de Paris [= BOP], D2/39.

Paris, Bibliothèque de l'Observatoire de Paris [= BOP], BOP, B4/2 (7).

Paris, Bibliothèque de l'Observatoire de Paris [= BOP], BOP, B4/3 (3); (25).

Paris, Bibliothèque de l'Observatoire de Paris [= BOP], BOP, B 4/9 (54bis); (55); (56).

Paris, Bibliothèque de l'Observatoire de Paris [= BOP], BOP, D2/39.

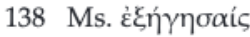

139 See the relevant database Pinakes: Textes et manuscrits grecs, https://pinakes.irht.cnrs.fr. 
[Anonymous], 'Sur le calendrier', Histoire de l'Académie royale des Sciences, a. 1701 (Paris 1704) $107-10$.

[Anonymous], 'Réflexions sur des Mémoires touchant la correction grégorienne communiquées par M. Bianchini à M. Cassini', Histoire de l'Académie royale des Sciences, a. 1704 (Paris 1704) 142-5.

[Anonymous], 'Sur l'éclipse de Lune du 5 Mars', Histoire de l'Académie Royale des Sciences, a. 1700 (Paris 1719) 109-11.

[Anonymous], 'Sur le calendrier', Histoire de l'Académie Royale des Sciences, a. 1701 (Paris 1719) 127-9.

[Anonymous], 'Sur les périodes lunisolaires ou sur le règlement des temps', in Histoire de l'Académie royale des Sciences, I. 1666-1686 (Paris 1733) 314-7.

[Anonymous], 'Diverses Observations Astronomiques', in Histoire de l'Académie royale des Sciences, I. 1666-1686 (Paris 1733) 381-3.

[Anonymous], 'Astronomie', in Histoire de l'Académie royale des Sciences, II. 1686-1699 (Paris 1733) 94-104.

[Anonymous], 'Sur le calendrier et sur la différence entre les cycles lunaires et solaires', Histoire de l'Académie royale des Sciences, II. 1686-1699 (Paris 1733) 318-22.

\section{Literature}

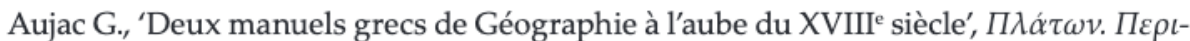

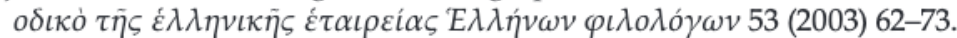

Bantyš-Kamenskij I. I., Reestry grečeskim delam Moskovskogo Arkhiva Kollegii inostrannykh del. Rossijskij Gosudarstvennyj arkhiv drevnikh aktov. Fond 52. Opis' 1, B.L. Fonkič (ed.) [Rossia i Khristianskij Vostok. Biblioteka, 2] (Moscow 2001).

Bellini G., Storia della Tipografia del Seminario di Padova (1684-1938) (Padua 1938).

Beretta F., 'L'héliocentrisme à Rome à la fin du XVII ${ }^{e}$ siècle: une affaire d'étrangers? Aspects structurels d'un espace intellectuel', in A. Romano (ed.), Rome et la science moderne. Entre Renaissance et Lumières (Rome 2008) 531-54.

Bernacki M. M., 'Dosifej II Notara, Patriarkh Ierusalimskij', in Pravoslavnaia Enciklopediia, vol. XVI (Moscow 2007) 71-7.

Besse J.-M., 'Le regard du cosmographe', in C. Hofmann and Fr. Nawrocki (eds), Le monde en sphères (Paris 2019) 118-23.

Bianu I. and Simonescu D. (ed.), Bibliografia Românească veche 1508-1830, IV (Bucharest 1944).

Callegari M., 'Strategie du produzione libraria a Padova nel Settecento', in G. Petrella (ed.), Navigare nei mari dell'umano sapere. Bibliotheche e circolazione libraria nel Trentino e nell'Italia del XVIII secolo. Atti del convegno di studio (Rovereto, 25-27 ottobre 2007) (Trent 2008) 33-43.

Cams M., 'Les missions jésuites en Extrême-Orient et les échanges de connaissances cartographiques (XVII - -XVIII ${ }^{e}$ siècles)', in C. Hofmann and Fr. Nawrocki (eds), Le monde en sphères (Paris 2019) 160-5.

Cassini J.-D., 'De l'origine et du progrès de l'astronomie et de son usage dans la géographie et dans la navigation', in Recueil d'observations faites en plusieurs voyages par ordre de Sa Majesté pour perfectionner l'Astronomie et la Géographie, avec divers Traités astronomiques, par Messieurs de l'Académie Royale des Sciences (Paris 1693) 1-43.

Cassini J.-D., Mémoires pour servir à l'histoire des sciences et à celle de l'Observatoire royal de Paris, suivis de la vie de J.-D. Cassini écrite par lui-même (Paris 1810). 
Cernovodeanu P. and Vătămanu N., 'Trois lettres inédites de Jean Comnène', Revue d'Histoire roumaine 11 (1972) 137-45.

Chu P., 'Scientific dispute in the Imperial Court: the 1664 calendar case', Chinese Science 14 (1997) 7-34.

Daliès N., 'Les archives à la Bibliothèque de l'Observatoire de Paris', Gazette des archives 179 (1997) 321-31.

Danjon A., 'Jean-Dominique Cassini et les débuts de l'Astrophysique', L'Astronomie 77 (1963) 4-16.

Dima-Drăgan C., Biblioteca unui umanist român Constantin Cantacuzino Stolnicul (Bucharest 1967).

- and Carataşu M., 'Un manuscrit inédit du Docteur Jean Comnène', Revue d'études sud-est européennes 11 (1971) 107-20.

Donato M. P., 'Scienza e Teologia nelle Congregazioni Romane. La questione atomista, 1626-1727', in A. Romano (ed.), Rome et la science moderne. Entre Renaissance et Lumières (Rome 2008).

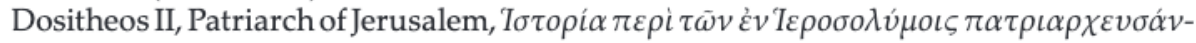
$\tau \omega \nu$ [History concerning the Patriarchs in Jerusalem] (Bucharest 1715 [ca 1722]).

Feuillée Louis, 'Extrait des observations astronomiques que le R. P. Feüillée Minime a faites au Levant pendant les années 1700 et 1701', Histoire de l'Académie royale des Sciences, a. 1702 (Paris 1743) 7-15.

Gabriel F., 'Tradition orientale et Vera Ecclesia : une critique hiérosolymitaine de la primauté pontificale. Nektarios, de Jassy à Londres (v. 1671-1702)', in M.-H. Blanchet and F. Gabriel (eds), Réduire le Schisme ? Ecclésiologies et politiques de l'union entre Orient et Occident (XIII-XVIII siècle) (Paris 2013) 197-236.

Gallois L., 'L'Académie des Sciences et les origines de la carte de Cassini', Annales de Géographie 99 (1909) 193-204; 100 (1909) 289-310.

Ghobrial J.-P., The Whispers of Cities. Information Flows in Istanbul, London, and Paris in the Age of William Trumbull (Oxford 2013).

Golvers N. and Nicolaidis E., Ferdinand Verbiest and Jesuit science in 17th century China: an annotated edition and translation of the Constantinople manuscript (1676) (AthensLeuven 2009).

Hamel J., 'Erhard Weigel und die Kalenderreform des Jahres 1700', in R. E. Schielicke, K1.-D. Herbst and St. Kratochwil (eds), Erhard Weigel-1625 bis 1999. Barocker Erzvater der deutschen Frühaufklärung (Frankfurt a.M. 1999) 135-56.

Hannick Chr. and Todt K-P., 'Jérémie II Tranos', in C. G. Conticello and V. Conticello (eds), La théologie byzantine et sa tradition, II. XIII $-X I X^{\mathrm{e}}$ s. (Turnhout 2002) 551-615.

Hurmuzaki E. (ed.), Documente privitoare la istoria Românilor, XIV/I. 1320-1716: Documente Greceşti (Bucharest 1915).

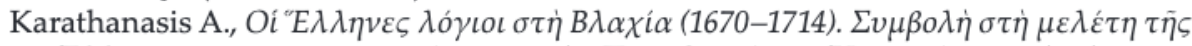

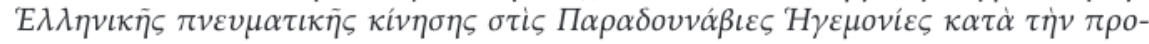

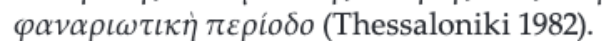

Koller E., Strittige Zeiten. Kalenderreformen im Alten Reich, 1582-1700 (Berlin-Boston 2014).

Kontouma V., 'Christianisme orthodoxe. Recherches sur Dosithée II de Jérusalem (1669-1707)', Annuaire de l'École pratique des hautes études 124 (2015-2016) 207-18.

- 'Christianisme orthodoxe. Recherches sur Dosithée II de Jérusalem (suite)', Annuaire de l'École pratique des hautes études 125 (2016-2017) 251-5. 


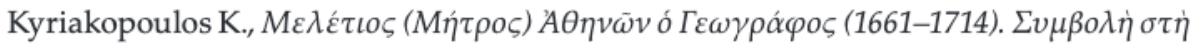

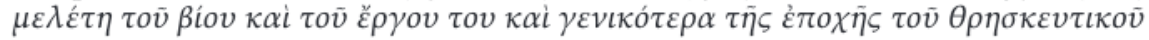

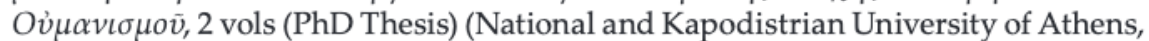
Athens 1990).

Lampadaridi A., 'La bibliothèque du Métochion du Saint-Sépulcre à Constantinople à travers ses inventaires anciens', in A. Binggeli, M. Cassin, M. Detoraki and A. Lampadaridi (eds), Bibliothèques grecques dans l'Empire ottoman (Leuven 2020) 291-310.

[Le Bouyer de Fontenelle B.], 'Sur l'Ancien Canon pascal de StHippolyte', Histoire de l'Académie royale des Sciences, II. 1686-1699 (Paris 1733) 300-17.

- 'Sur les deux éclipses de cette année, et principalement sur celle de Lune, employée à l'examen du calendrier', Histoire de l'Académie royale des Sciences, II. 1686-1699 (Paris 1733) 322-31.

Legrand E. (ed.), Bibliothèque grecque vulgaire, III (Paris 1881).

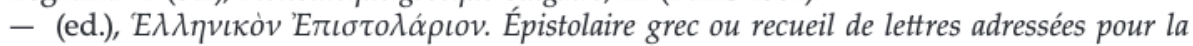
plupart à Chrysanthe Notaras patriarche de Jérusalem par les princes de Valachie et de Moldavie (Paris 1888).

- (ed.), Bibliographie hellénique ou description raisonnée des ouvrages publiés par des Grecs au dix-septième siècle, II (Paris 1894).

Leibniz G.W., Sämtliche Schriften und Briefe. Dritte Reihe: Mathematischer, naturwissenschaftlicher und technischer Briefwechsel, VIII (Berlin-Boston 2015).

Lequien M., Oriens christianus in quatuor patriarcatus digestus, III (Paris 1740).

Lerner M.-P., 'L'entrée de Tycho Brahe chez les jésuites ou le chant du cygne de Clavius', in L. Giard (ed.), Les Jésuites à la Renaissance. Système éducatif et production du savoir (Paris 1995) 145-85.

Livieratos E., Boutoura Chr., Pazarli M., Ploutoglou N. and Tsorlini A., 'The very first printed map in Greek, a derived map from Dutch cartography: Chrysanthos Notaras' world map (1700) vs Jan Luyts' world map (1692)', e-Perimetron 6/3 (2011) 200-18.

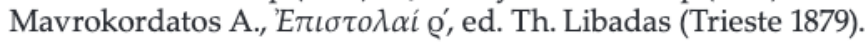

Nicolaidis E., Science and Eastern Orthodoxy. From the Greek Fathers to the Age of Globalization, transl. Susan Emanuel (Baltimore MD 2011).

- 'Verbiest, Spathar and Chrysanthos. The spread of Verbiest's science to Eastern Europe', in W. F. Vande Walle and N. Golvers (eds), The History of the Relations Between the Low Countries and China in the Qing Era (1644-1911) (Leuven 2003) 37- 57.

[Nicolopoulo C.-A.], 'Notaras (Chrysanthe)', in L.-G. Michaud (ed.), Biographie universelle, ancienne et moderne ..., XXXI (Paris 1822) 404-5.

Nilles N., Symbolae ad illustrandam historiam ecclesiae orientalis in Terris coronae S. Stephani, I (Eniponte [= Innsbruck] 1885).

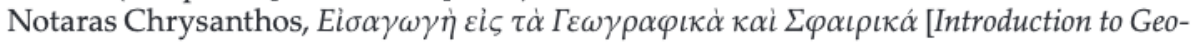
graphics and Sphaerics] (Paris 1716).

Omont H. (ed.), Missions archéologiques françaises en Orient aux XVII et XVIII ${ }^{e}$ siècles, I (Paris 1902).

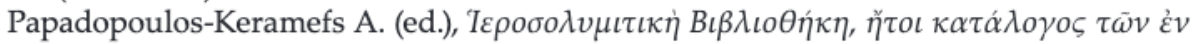

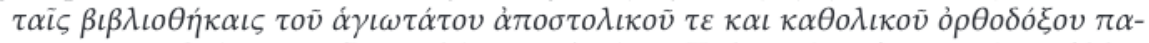

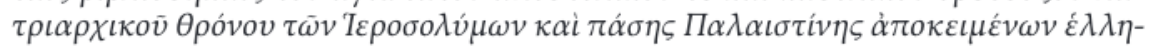
$v \iota \kappa \bar{\omega} v \kappa \omega \delta i \kappa \omega v$, III (St Petersburg 1897).

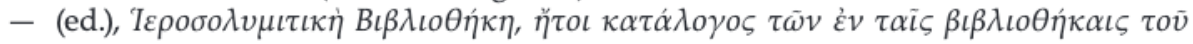

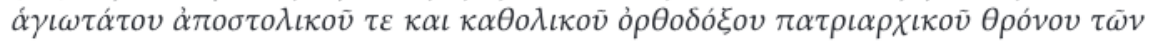




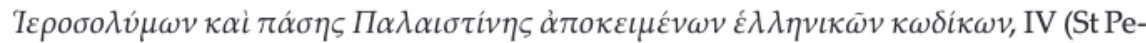
tersburg 1899).

Petit N., 'La Byzantine du Louvre', in M.-F. Auzépy and J.-P. Grélois (eds), Byzance retrouvée. Érudits et voyageurs français (XVI $-X V I I I^{e}$ siècles). Catalogue de l'exposition. Chapelle de la Sorbonne, Paris, 13 août-2 septembre 2001 (Paris 2001) 70-84.

Picolet G., 'Une visite du jeune Saint-Simon à l'Observatoire de Paris', Cahiers Saint-Simon 26 (1988) 59-68.

Prokopiou Pamperis Dimitrios, 'Demetrii Procopii, Macedonis Moschopolitae, 'E $\pi$ t-

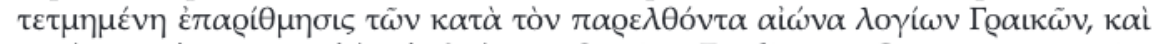

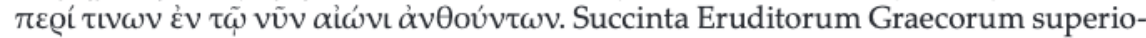
ris et praesentis saeculi recensio, conscripta mense Junio A.C. MDCCXX transmissaque Bucuresto, et nunc primum edita, cum Latina versione', in J. A. Fabricius (ed.), Bibliotheca Graeca, XI (Hamburg 1722) 769-808.

Radau R., 'L'Observatoire de Paris depuis sa fondation', Revue des Deux Mondes [2nd Period] 73 (1868) 740-68.

Romano A., 'L'horizon romain de la science moderne. Des sentiers à ouvrir', in A. Romano (ed.), Rome et la science moderne. Entre Renaissance et Lumières (Rome 2008) 637-59.

Saliba G., 'The role of Maragha in the development of Islamic Astronomy: a scientific revolution before the Renaissance', Revue de synthèse 4/3-4 (1987) 361-73.

- 'Revisiting the astronomical contacts between the World of Islam and Renaissance Europe: the Byzantine connection', in P. Magdalino and M. Mavroudi (eds), The Occult Sciences in Byzantium (Geneva 2006) 361-74.

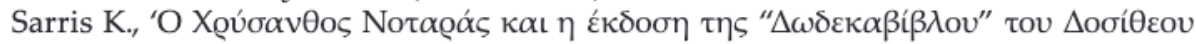

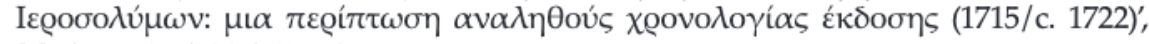
Mvं $\mu \omega \nu 27$ (2005) 27-53.

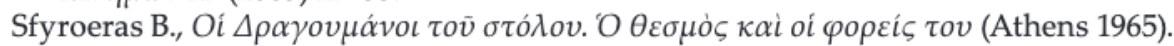

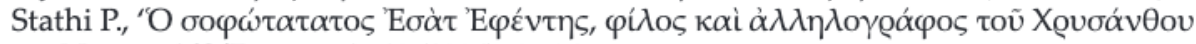

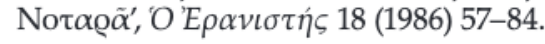

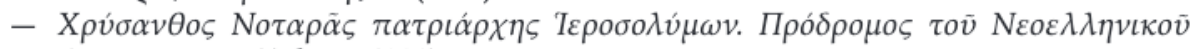
$\Delta \iota \alpha \varphi \omega \tau \iota \sigma \mu o \tilde{v}$ (Athens 1999).

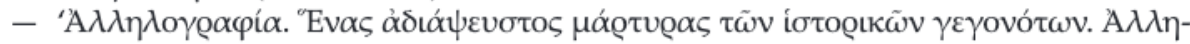

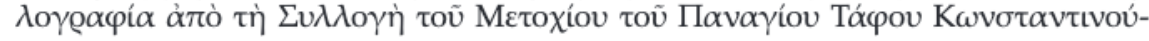
$\pi \mathrm{o} \lambda \eta \varsigma^{\prime}$, in E. Close, M. Tsianikas and G. Couvalis (eds), Greek Research in Australia: Proceedings of the Sixth Biennial International Conference of Greek Studies, Flinders University, June 2005 (Adelaide 2007) 389-400.

Tappe E. D., 'Documents concerning Rumania in the Paget papers', The Slavonic and East European Review 33/80 (December 1954) 201-11.

Todt K.-P., 'Dositheos II. von Jerusalem', in C. G. Conticello and V. Conticello (eds), La théologie byzantine et sa tradition, II. (XIII $-X I X^{e}$ s.) (Turnhout 2002) 659-720.

Tolias G., 'Maps printed in Greek during the Age of Enlightenment, 1665-1820', e-Perimetron 5/1 (2010) 1-48.

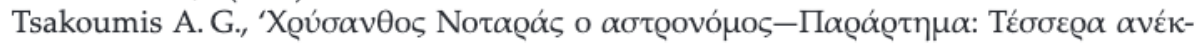

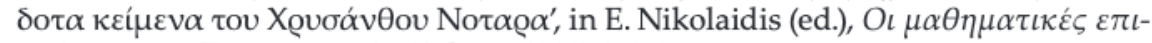

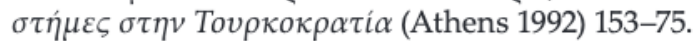

Tsourkas $\mathrm{Cl}$., Les débuts de l'enseignement philosophique dans les Balkans. La vie et l'œuvre de Théophile Corydalée (1570-1646) (Thessaloniki 1967). 
Tzoga V., 'Sigillion inédit du patriarche de Constantinople Jérémie II et d'Alexandre Sylvestre sur la réforme du calendrier', Byzantinische Zeitschrift 107 (2014) 221-52.

Van der Krogt P., 'L'usage des globes dans la société européenne aux XVIe-XVII ${ }^{e}$ siècles', in C. Hofmann and Fr. Nawrocki (eds), Le monde en sphères (Paris 2019) 144-50.

Vasiliu V., 'Costantino Brâncoveanu e il Cattolicismo. Alcune notizie nuove intorno alla sua politica religiosa', Ephemerides Dacoromana. Annuario della Scuola romena di Roma 3 (1925) 110-28. 